\title{
The Alchemy of Junk: Patent Law and Non-Coding DNA
}

\author{
Matthew Rimmer*
}

THIS ARTICLE CONSIDERS THE RECENT INTERNATIONAL CONTROVERSY over the patents held by a Melbourne firm, Genetic Technologies Limited (GTG), in respect of non-coding DNA and genomic mapping. It explores the ramifications of the GTG dispute in terms of licensing, litigation, and policy reform, and-as a result of this dispute-the perceived conflict between law and science. GTG has embarked upon an ambitious licensing program with twenty seven commercial licensees and five research licensees. Most significantly, GTG has obtained an exclusive licence from Myriad Genetics to use and exploit its medical diagnostics in Australia, New Zealand, and the Asia-Pacific region. In the US, GTG brought a legal action for patent infringement against the Applera Corporation and its subsidiaries. In response, Applera counterclaimed that the patents of GTG were invalid because they failed to comply with the requirements of US patent law, such as novelty, inventive step, and written specifications. In New Zealand, the Auckland District Health Board brought legal action in the High Court, seeking a declaration that the patents of GTG were invalid, and that, in any case, the Board has not infringed them. The New Zealand Ministry of Health and the Ministry of Economic Development have reported to Cabinet on the issues relating to the patenting of genetic material. Similarly, the Australian Law Reform Commission (ALRC) has also engaged in an inquiry into gene patents and human health; and the Advisory Council on Intellectual Property (ACIP) has considered whether there should be a new defence in respect of experimental use and research.

CET ARTICLE FAIT UN SURVOL DE LA CONTROVERSE INTERNATIONALE RÉCENTE au sujet des brevets de l'entreprise Genetic Technologies Limited (GTG) de Melbourne relativement à l'ADN non codant et à la cartographie génonémique. Il explore les ramifications du différend de la GTG en matière de la concession de licences, du contentieux et de la réforme des politiques. Ce différend apportera un éclairage sur le conflit perçu entre le droit et la science. La GTG a entrepris un ambitieux programme de concession de licences avec vingt-sept titulaires de licences commerciales et cinq titulaires de licences de recherche. En particulier, la GTG a obtenu une licence exclusive de Myriad Genetics pour l'utilisation et l'exploitation de ses diagnostics médicaux en Australie, en NouvelleZélande et dans la région Asie Pacifique. Aux États-Unis, la GTC a intenté une action en justice contre Applera Corporation et ses filiales pour violation de ses brevets. Applera a répliqué en alléguant I'invalidité des brevets de la GTG au motif que ceux-ci dérogeaient aux normes américaines du droit des brevets, notamment en ce qui a trait à la nouveauté, à l'activité inventive et aux spécifications écrites. En Nouvelle-Zélande, la Commission de santé du district de Auckland a déposé une action devant la Haute Cour en demandant une déclaration d'invalidité des brevets de la GTG et, qu'il y ait ou non invalidité, que la Commission n'avait pas porté atteinte à ces brevets. Le ministère de la Santé et le ministère du Développement économique de la Nouvelle-Zélande ont fait un rapport au Cabinet relativement au brevetage du matériel génétique. Similairement, la Commission de réforme du droit de l'Australie a fait enquête sur les licences de matériel génétique et la santé humaine. Le conseil consultatif de la propriété intellectuelle a cherché à déterminer s'il y a lieu de développer une nouvelle défense en matière des utilisations et des recherches expérimentales.

Copyright (? 2006 by Matthew Rimmer

* Matthew Rimmer, BA (Hons)/LLB (Hons) (ANU), PhD (UNSW), is a Senior Lecturer at ACIPA in the ANU College of Law, Canberra, email: <Matthew.Rimmer@anu.edu.au>. The author is grateful for discussions with members of the Australian scientific community. He is also thankful for the help of his research assistants, Elsa Gilchrist, Katrina Gunn, and Kellie Johnston. This research has been supported by an ARC Discovery Project, "Gene Patents in Australia: Options for Reform." 
1. INTRODUCTION

2. MYRIAD GIFTS: COMMERCIAL LICENCES AND PEPPERCORN RENTS
2.1. Commercial Licences

2.2. Research Licences

2.3. Cross-Licensing Agreement with Myriad Genetics

2.4. Patent Revocation

3. JUNKYARD DOGS: GENETIC TECHNOLOGIES LIMITED

V. APPLERA CORPORATION

3.1. Applera Activities

3.2. Patent Infringement

3.3. Answer and Counterclaims

3.4. Settlement

4. TRANS-TASMAN RIVALRY: THE AUCKLAND DISTRICT HEALTH BOARD V. GENETIC TECHNOLOGIES LIMITED
4.1. Licensing

4.2. Litigation

4.3. Settlement

5. GENE PATENTING AND HUMAN HEALTH: THE AUSTRALIAN LAW REFORM COMMISSION INQUIRY

5.1. Political Debate

5.2. Final Report

5.3. Government Responses

6. CONCLUSION 


\title{
The Alchemy of Junk: Patent Law and Non-Coding DNA
}

\author{
Matthew Rimmer
}

1. INTRODUCTION

Genius of Junk is the story of how Malcolm Simons turned Junk into gold, enflaming one of the greatest controversies of our time-the control and ownership of our genetic material. [...] This is also a story of genius and character. Malcolm Simons had the genius to realise that the non-coding part of our DNA wasn't in fact the junk DNA that many scientists had labelled it, but vital to the processes of life. And he has a character that fits the cliché of the eccentric scientist—brilliant at his work but hopeless with everyday life. ${ }^{1}$

GeneType was founded in 1989 by immunologist Dr Malcolm Simons and medical practitioner Dr Mervyn Jacobson. Their website provides this foundation story:

GeneType was founded in 1989 when Dr. Malcolm Simons (an immunogeneticist) and Dr. Mervyn Jacobson (a medical practitioner) met in Melbourne, Australia, and resolved to prove the non-coding ("junk" DNA) region of the human HLA gene complex [the human leukocyte antigen system] on Chromosome 6 is in reality not "junk," but in fact a valuable and highly ordered reservoir of useful genetic information, largely overlooked by the rest of the world. The commercial mission then evolved that Gene Type would seek exclusive ownership over access to this important genetic information and ultimately, to exploit it globally for profit. ${ }^{2}$

Genetic Technologies Limited (GTG) was the result of a merger in 2000 between the original holding company, the private Swiss-owned

1. "Genius of Junk (DNA)," Catalyst (Australian Broadcasting Corporation, 10 July 2003), <http://www.abc.net. au/catalyst/stories/s898887.htm> ["Genius of Junk (DNA)"].

2. Genetic Technologies Limited, "Corporate Details" (February 2003), available at: <http://web.archive.org/ web/20030207163028/www.gtg.com.au/CorpDetails.html>. 
GeneType AG, and a publicly listed Australian company, Duketon Goldfields Limited. ${ }^{3}$ After the corporate restructuring, GTG set a new goal of conversion to a biotechnology company.

GTG was able to obtain broad patents on a range of scientific inventions arising out of the work of Malcolm Simons. ${ }^{4}$ Most significantly, the United States Patent and Trademark Office (USPTO) awarded US Patent No. 5,612,179 to GTG for an invention entitled "Intron sequence analysis method for detection of adjacent and remote locus alleles as haplotypes. ${ }^{5}$ Furthermore, the USPTO also issued US Patent No. 5,851,762 to GTG for an invention entitled "Genomic mapping method by direct haplotyping using intron sequence analysis." 6 The company has also applied for patents in respect of foetal cell recovery, retroviralimmuno therapy, and an ACTN3 genotype screen for athletic performance. ${ }^{7}$ Jacobson comments with the following:

\begin{abstract}
People, with our cooperation, developed things for everything from cattle to cats and plants to show that what was discovered in HLA was not the exception but the paradigm. "It was a very visionary patent attorney who recognised how to use the rules of the patent process to apply our work to genes in all species." ${ }^{\prime 8}$
\end{abstract}

A wide spectrum of the community could be affected by the patents related to non-coding DNA. GTG asserts that its genomic mapping methods can deal with monogenic diseases such as cystic fibrosis, sickle-cell anaemia, and beta-thalassemia. Furthermore, it suggests that its markers can help identify multigenic diseases such as diabetes, colon cancer, and breast and ovarian cancer. In addition to identifying individuals at risk for genetic diseases, GTG argues that its patented inventions could be used in respect of forensics and paternity testing. The company also asserts that the patents have wider implications for agriculture because they are relevant to the genetic testing of plants and animals. ${ }^{9}$

GTG is the holding company of several subsidiaries including GeneType Pty Limited, Simons GeneType Diagnostics Pty Limited, Genetic Technologies Corporation Pty Limited, Silbase Scientific Services Pty Limited, RareCellect Limited, ImmunAid Pty Limited, AgGenomics Pty Limited, GeneType AG, and GeneType Corporation. Another potential opportunity for growth comes from

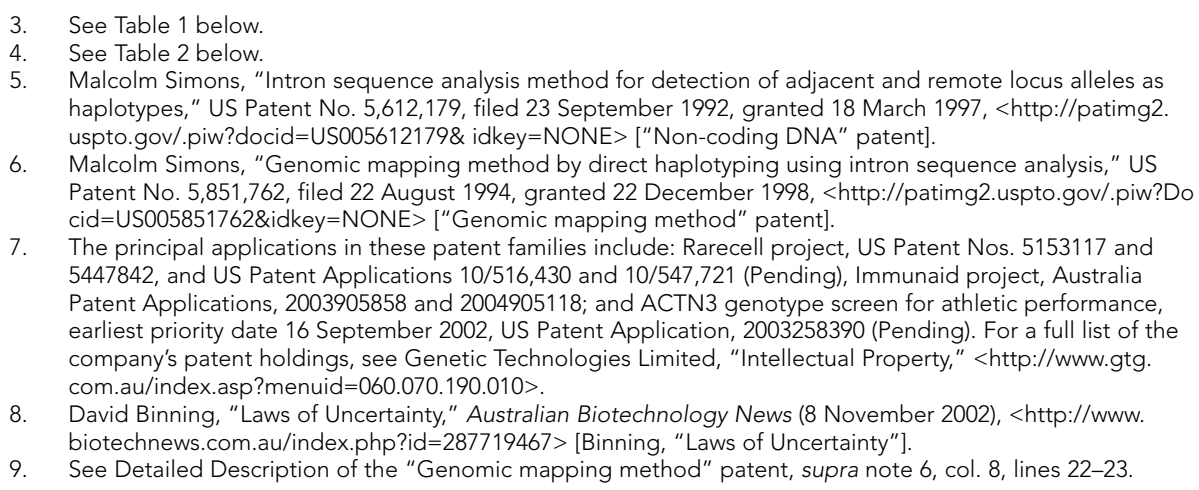

6. Malcolm Simons, "Genomic mapping method by direct haplotyping using intron sequence analysis," US Patent No. 5,851,762, filed 22 August 1994, granted 22 December 1998, <http://patimg2.uspto.gov/.piw?Do cid=US005851762\&idkey=NONE> ["Genomic mapping method" patent].

7. The principal applications in these patent families include: Rarecell project, US Patent Nos. 5153117 and 5447842, and US Patent Applications 10/516,430 and 10/547,721 (Pending), Immunaid project, Australia Patent Applications, 2003905858 and 2004905118; and ACTN3 genotype screen for athletic performance, earliest priority date 16 September 2002, US Patent Application, 2003258390 (Pending). For a full list of the company's patent holdings, see Genetic Technologies Limited, "Intellectual Property," <http://www.gtg. com.au/index.asp?menuid=060.070.190.010 .

8. David Binning, "Laws of Uncertainty," Australian Biotechnology News (8 November 2002), <http://www. biotechnews.com.au/index.php?id=287719467> [Binning, "Laws of Uncertainty"].

9. See Detailed Description of the "Genomic mapping method" patent, supra note 6, col. 8, lines 22-23. 
GTG's 75.8 percent share of Canadian subsidiary GTech, a Vancouver-listed former mining company, which is also looking to convert to a biotechnology focus in the near future. ${ }^{10}$

Long-term, GTG aspires to become a comprehensive centre for "genetic testing business in the Asia Pacific region."11 With entrepreneurial bravado, Jacobson predicted: "Our mission in relation to service testing now is to become the leading genetic testing facility in the Asia-Pacific region-the biggest and the best." 12 Since the 1990s, the company has provided genetic testing in the field of disputed paternity. It currently provides paternity testing services to Queensland Legal Aid. AgGenomics Pty Ltd., the joint venture with Agriculture Victoria Services Pty Ltd., provides genetic testing and genomic services at the Plant Biotechnology Centre at La Trobe University, focussing mainly on plant and agricultural opportunities. In October 2002, GTG joined with Myriad to announce a strategic alliance in comprehensive cancer susceptibility testing. GTG would offer such testing in Australia, New Zealand, and South East Asia, and Myriad would offer such testing in the rest of the world. In 2004, GTG announced that it would provide forensic testing at its laboratory services. ${ }^{13}$ In 2005, GTG was listed on the NASDAQ, a move which the company hopes will give it access to capital markets in the US. ${ }^{14}$ The company has also enlisted the former Australian treasurer, John Dawkins, as a director. ${ }^{15}$

Controversially, GTG has demanded large licence fees from private companies for access to its patents in respect of non-coding and genomic mapping. ${ }^{16}$ The Australian firm has issued twenty-seven commercial licences to biotechnology companies. The licences cover a range of activities, including plant genomics; animal testing; human genetic diagnostics; paternity and pathology testing; and the development of reagents. The licensees originate from the United States, Canada, the European Union, Australia, and New Zealand. However, this aggressive licensing strategy has met with some resistance. Several United States companies-including Myriad Genetics, Nuvelo Inc., Covance Inc., LabCorp, and Applera-initially brought legal action against GTG before reaching a settlement. ${ }^{17}$ There has also been legal action over the validity of the patents of GTG in New Zealand. After being asked to pay considerable patent royalties, the Auckland District Health Board brought an action against GTG, alleging groundless threats of legal proceedings. The matter was withdrawn after mediation, with the parties bearing their respective costs.

10. Genetic Technologies Limited, Annual Report 2005, <http://esvc001057.wic005u.server-web.com/ archives/1/070.130/822/Release\%20of\%202005\%20Annual\%20Report.pdf> at p. 29 [GTG, Annual Report 2005].

11. Genetic Technologies Limited, "GTG reports growth in revenue from Genetic Testing" (23 July 2004), <http://www.gtg.com.au/index.asp?menuid=060.070.130.010\&artid=155> [GTG, "Growth in Revenue from Genetic Testing"].

12. Melissa Trudinger, "BIO Profile: Mervyn Jacobson, Genetic Technologies," Australian Biotechnology News (1 June 2004), <http://www.biotechnews.com.au/index.php?id=218823635> [Trudinger, "BIO Profile: Mervyn Jacobson"].

13. GTG, "Growth in Revenue from Genetic Testing," supra note 11.

14. Genetic Technologies Limited, "GTG celebrates NASDAQ listing with the ringing of the Stock Market Closing Bell" (7 November 2005), <http://www.gtg.com.au/index.asp?menuid=060.070.130\&artid=292\&func tion=NewsArticle>

15. Genetic Technologies Limited, "John Dawkins Joins GTG Board of Directors" (25 November 2004), <http:// www.gtg.com.au/index.asp?menuid=060.070.130.010\&artid=174>.

16. See Table 3 below.

17. See Table 4 below. 
However, a number of Crown Research Institutes in New Zealand agreed to pay commercial licensee fees to GTG. ${ }^{18}$

GTG has encouraged universities and research institutions to take out research licences to use its patents on non-coding DNA and genomic mapping. In response, public researchers have raised doubts about the inventiveness of the patents held by GTG. The leaders of the public consortium of the Human Genome Project were particularly vocal in their concerns. The director of the US National Human Genome Research Institute, Dr Francis Collins, condemned the privatisation of the human genome through the patent system. He observed that GTG had broken with a scientific tradition to provide free access to patented materials to academics conducting basic research:

The real question, it seems to me- "Is this good for the public?" If pursuing an aggressive stance with this patent slows down the progress of scientific research, then the public is injured and you and I should object. ${ }^{19}$

Similarly, his colleague, British Nobel Laureate Sir John Sulston, the former Director of the Wellcome Trust Sanger Institute, argued that enforcing the patents was "going to be obviously extremely destructive." 20 He observed, "it's going to prevent a lot of important work in health care." ${ }^{21}$ His concern was that science was swinging more towards the profit motive, which was destroying credibility and trust.

This article considers the recent international controversy over the patents held by GTG in respect of non-coding DNA and genomic mapping. ${ }^{22}$ It questions whether Simons is a "genius of junk," and whether his patents have the requisite novelty and inventiveness, according to the scientific knowledge at that time. Part 2 considers the licensing strategy of GTG, in particular the crosslicensing agreements with Myriad and Myriad's recent setbacks in Europe where the European Patent Office (EPO) has revoked one of its patents dealing with Breast Cancer Gene 1 [BRCA1], and awarded Michael Stratton and Cancer Research UK a patent dealing with Breast Cancer Gene 1 [BRCA2]. Myriad may appeal such decisions. Part 3 focuses on the litigation between GTG and Applera. In the United States, GTG brought a legal action for patent infringement against Applera and its subsidiaries. Applera denied such allegations and

18. Genetic Technologies Limited, "Mediation in New Zealand Results in Final Settlement of Legal Action" (7 July 2005), <http://www.gtg.com.au/index.asp?menuid=060.070.130\&artid=244\&function=NewsArticle>

19. Jonathan Holmes, "Patently a Problem," Four Corners (Australian Broadcasting Corporation, 11 August 2003), transcript, <http://www.abc.net.au/4corners/content/2003/transcripts/s922059.htm> [Holmes, "Patently a Problem"].

20. Ibid.

21. Ibid.

22. This case study is part of the larger policy debate over gene patents. There is a large literature on this topic. See Michael Heller \& Rebecca Eisenberg, "Can Patents Deter Innovation? The Anticommons in Biomedical Research," (1998) 280:5364 Science 698, <http://www.sciencemag.org/cgi/content/full/280/5364/698>; Nuffield Council on Bioethics, The Ethics of Patenting DNA, A Discussion Paper (London: Nuffield Council on Bioethics, 2002), <http://www.nuffieldbioethics.org/go/ourwork/patentingdna/publication_310.html>; Dianne Nicol \& Jane Nielsen, "Patents and Medical Biotechnology: An Empirical Analysis of Issues Facing the Australian Industry," Occasional Paper No. 6 (Centre for Law and Genetics, University of Tasmania, 2003), <http://www.ipria.org/publications/workingpapers/BiotechReportFinal.pdf >; Centre for Intellectual Property Policy [Richard Gold et al.], Genetic Patents and Health Care in Canada: An International Comparison of Patent Regimes of Canada and its Major Trading Partners (Montreal: McGill Centre for Intellectual Property Policy, 2005), <http://www.cipp.mcgill.ca/data/publications/00000015.pdf>. 
counterclaimed that the patents of GTG were invalid because they failed to comply with the requirements of US patent law such as novelty, inventive step, and written specifications. The matter was eventually settled. Part 4 examines parallel litigation in New Zealand. In New Zealand, the Auckland District Health Board brought an action against GTG in the Auckland High Court (in which it questioned the validity of the patents, claiming that it did not infringe such patents), and the Ministry of Health and the Ministry of Economic Development have reported to cabinet on the issues relating to the patenting of genetic material. ${ }^{23}$ Part 5 considers the policy developments resulting from the controversy over patent law and non-coding DNA in Australia. The Australian Law Reform Commission (ALRC) has undertaken an inquiry into gene patents and human health, ${ }^{24}$ and the Advisory Council on Intellectual Property (ACIP) is considering whether there should be a new defence in respect of experimental use and research. ${ }^{25}$

\section{MYRIAD GIFTS: COMMERCIAL LICENCES AND PEPPERCORN RENTS}

AT THE FIRST ANNUAL GENERAL MEETING in November 2000, Jacobson reported to GTG stockholders that "the strategy was to licence the GeneType patentsespecially the so-called 'non-coding' patents, in order to generate future revenue for GTG."26 In the company's 2001 Annual Report, Jacobson observed that "some companies typically deny they need a licence from GTG—but significantly, they cannot explain how else they might achieve the results they now seek." $27 \mathrm{He}$ remarked, "[i]t has recently been suggested that in order to expedite these negotiations, GTG should now take a hard line with at least one potential licensee, given the prevailing view that most companies do not want to be the first to take a license to new technology." 28

In 2001, GTG obtained patent insurance from General Electric Reinsurance. Jacobson explains the precautionary motivation behind the company seeking such insurance in the biotechnology industry:

23. New Zealand, Ministry of Health and Ministry of Commerce, Memorandum to Cabinet Policy Committee: Report Back with Recommendations and Options for Addressing Genetic Material Patents (May 2004), <http://www.med.govt.nz/templates/MultipageDocumentTOC__1148.aspx> [Options for Addressing Genetic Material Patents].

24. Australian Law Reform Commission, "Gene Patenting and Human Health," Issue Paper 27 (Sydney: Australian Commonwealth, July 2003), <http://www.austlii.edu.au/au/other/alrc/publications/issues/27/> ["Gene Patenting and Human Health," Issue Paper]; Australian Law Reform Commission, "Gene Patenting and Human Health," Discussion Paper 68 (Sydney: Australian Commonwealth, February 2004), <http://www. austlii.edu.au/au/other/alrc/publications/dp/68/> ["Gene Patenting and Human Health," Discussion Paper]; and Australian Law Reform Commission, "Genes and Ingenuity: Gene Patenting and Human Health," Report 99 (Sydney: Australian Commonwealth, June 2004), <http://www.austlii.edu.au/au/other/alrc/ publications/reports/99> ["Genes and Ingenuity"].

25. Advisory Council on Intellectual Property, "Patents and Experimental Use," Options Paper (Canberra: Commonwealth Government, 2004), <http://www.acip.gov.au/library/Experimental\%20Use\%200ptions\%20 Paper\%20A.pdf> ["Patents and Experimental Use"].

26. Genetic Technologies Limited, Annual Report 2001, <http://admin.gtg.net.au/archives/1/070.040/190/2001G TGAnnualReport.pdf> at p. 3 [GTG, Annual Report 2001].

27. Ibid at p. 4.

28. Ibid at p. 4. 
Typically $[\ldots]$ the big companies would dismiss the small companies, ignore it or if it became a nuisance it may well enter into some legal interaction whereby they would just exhaust that little company financially. For a major multinational biotech to spend $\$ 5$ or $\$ 6$ million to get rid of a threat is probably not a big deal. For the little biotech company, it may be the end of the road, their destruction. So we had the foresight in the early days to take out what's called patent insurance, that our patents, once issued, would be insured and if we indeed had to enter into some legal dispute with larger companies, that to a degree the playing field would be levelled, the costs of prosecuting our patents and proving that they are infringing and they need a licence is covered by the insurer. So we don't run the risk of wiping ourselves out in the process. ${ }^{29}$

Jacobson is somewhat coy about the nature of this policy, claiming that he cannot reveal the terms of the agreement. He could only confirm that the policy was very expensive, noting "it was a significant investment for us as a small group at the time but was deemed to be a prudent investment and with hindsight, was a wise decision." ${ }^{30}$ The scope of the patent insurance is a mystery; it remains to be seen whether it would fully cover the costs of any patent infringement action. There has been much wider discussion over the costs associated with offensive and defensive insurance coverage for patent infringement. ${ }^{31}$ According to the 2004 annual report, the insurance policy has since expired. ${ }^{32}$ It is unclear whether GTG has been successful in obtaining a new insurance policy in respect of patent infringement.

In May 2003, GTG reported that it had identified 1783 potential licensees, such as genomics companies, genetic testing firms, developers of diagnostic devices, pharmaceutical and bioinformatics companies, owners of proprietary genes and genetic researchers. ${ }^{33}$ It alleged that at least 475 groups had already infringed the patents. The company emphasised that it was pursuing "several new opportunities protected by its [GeneType's] patents in the areas of human, animal and plant genetic diagnostics and genomics." 34 In particular, short-term priorities would be "the licensing of the non-coding sequence patents, reduction to practice of the foetal cell patents and the expansion of the service testing business," as well as the possibility of collaborating "with other scientific groups to commence suitably promising opportunities in biotechnology, both in Australia and overseas." 35

Jacobson comments: "It's all about being creative [with the licensing terms]_every licensing deal we make is different, unique." ${ }^{36}$ GTG developed a

29. Jonathan Holmes, "Interview with Dr Mervyn Jacobson" (11 August 2003), <http://www.abc.net.au/4corners/ content/2003/20030811_patent/int_jacobson.htm> [Holmes, "Interview with Dr Mervyn Jacobson"].

30. Ibid.

31. Lisa Small, "Offensive and Defensive Insurance Coverage for Patent Infringement Litigation: Who will Pay?" (1998) 16:2-3 Cardozo Arts \& Entertainment Law Journal 707, <http://www.cardozoaelj.net/issues/98 /Small.pdf>.

32. Genetic Technologies Limited, Annual Report 2004, <http://esvc001057.wic005u.server-web.com/ archives/1/070.040/190/GTG\%20AR\%2004.pdf > at p. 10.

33. Guy Nolch, "King of Junk DNA Files New Patents," (2003) 24:7 Australasian Science 4.

34. GTG, Annual Report 2001, supra note 26 at p. 3.

35. Ibid.

36. Trudinger, "BIO Profile: Mervyn Jacobson," supra note 12. 
two-tier scheme for the licensing of its patents related to non-coding DNA and genomic mapping. The company would offer a commercial licence to private biotechnology companies in order to generate revenue. The firm would offer a research licence to public entities for a lower, and, in some cases, nominal fee. GTG maintained that the company sought to encourage as many users of its patented inventions as possible and thus was willing to provide licences to all users. ${ }^{37}$

\subsection{Commercial Licences}

GTG has issued twenty-seven commercial licences to a range of companies. The commercial licences cover a range of activities in the field of genomics and biotechnology: human genetic diagnostics; paternity and pathology testing; the development of reagents and biochips; genetic testing of livestock and aquaculture; and, plant genomics. The majority of the companies are from the United States, including Sequenom Inc., Nanogen Inc., Perlegen Sciences Inc., Myriad, ARUP, Orchid Biosciences Inc., Quest Diagnostics Limited, and Laboratory Corporation of the United States. One of the American companies, Inguran, has a substantial business in Latin America. There is one licensee from Canada: TM Biosciences Corporation. There are also a couple of European representatives: Pyrosequencing $A B$ from Sweden and Innogenetics NV of Belgium. There are few licensees from Australia and New Zealand. The value of the commercial licences ranged from AU\$125,000 to AU\$15 million. However, many of the arrangements remain confidential. ${ }^{38}$

Such commercial licences have been controversial. On 31 January 2002, Sequenom Inc., a discovery genetics company interested in the development of products to determine the medical impact of genes and genetic variation, was granted a non-exclusive licence over the GeneType non-coding patents for genomic mapping and intron sequence analysis effective from 5 April 2002. The licence includes the use of SNPs, mutations, and markers located in the noncoding DNA. Under the licence, Sequenom will pay at least AU\$1 million in upfront licence fees. Sequenom has been assured that future licences to other companies will not be for less than what they paid. ${ }^{39}$

However, Dr Charles Cantor, the Chief Scientific Officer of Sequenom Inc., was uncomplimentary about the methods of GTG:

It's very hard to disable an issued patent. While I didn't think the patent was terribly strong—it wasn't an absolutely clear-cut case-in my view it would be a protracted court fight. I felt we would win it in the end, but it wasn't worth it. What made the license attractive is that we had the ability to pass on the sublicense to our customers. This meant that people who use things that read more closely on the patent would still be able to get access to the patent. ${ }^{40}$

37. Ibid.

38. See Table 3.

39. Genetic Technologies Limited, "GTG Secures $\$ 1$ Million License from Sequenom" (8 April 2002), <http:// www. gtg.com.au/index.asp? menuid=060.070.200.020.010\&artid $=221>$.

40. "A Patent's Place," Bio-IT World (13 August 2003), <http://www.bio-itworld.com/archive/081303/horizons aussie_sidebar_1.html> ["Patent's Place"]. 
Cantor said in the Four Corners report: "The amount of pressure they put on us to come to a conclusion one way or another was [...] blackmail." $41 \mathrm{He}$ was conscious of the threat of litigation: "We're going to take you to court and it's going to cost you so much money to defend yourself that you're better off just paying us what we're asking for and we'll go away and you'll never hear from us again." 42

On 17 November 2003, [GTG] reported that the lawsuits filed by GTG against US biotechnology companies, Nuvelo, Inc., and Covance, Inc., in March 2003 for infringement against the GTG patents, had been finally settled by negotiations between the parties. [GTG reported] that the US District Court for the Northern District of California formally dismissed these lawsuits-at the request of the parties. Again, the specific details of the agreed settlements negotiated between GTG and the other parties [...] remain confidential. ${ }^{43}$

On 9 February 2004, GTG reported that LabCorp had obtained a commercial licence. ${ }^{44}$ Initially, LabCorp filed a declaratory judgment action against GTG in the US District Court for the District of New Jersey; however, having obtained a licence from GTG, LabCorp withdrew its action.

In 2004, GTG announced the establishment of a broad strategic alliance with the CY O'Connor ERADE Village Foundation (CYO), a centre of biotechnology in Western Australia. Initially, five genetics and genomics projects will be selected for priority attention and GTG will provide AU $\$ 4.5$ million to CYO, spread over five years, to help fund such research and the development of new intellectual property. 45

In 2006, GTG formed a strategic alliance with MetaMorphix Inc., a licensee to its non-coding patents. ${ }^{46}$ The two companies intend to engage in joint commercialization of research. GTG will introduce MetaMorphix's new genetic tests for livestock and companion animals into Australia and New Zealand. In particular, the company will focus upon horn-polling markers, which, "allow cattle breeders to identify and breed out cattle born with horns." 47

In 2006, GTG has sought to expand its global licensing program by recruiting additional resources, including additional licensing staff and legal support teams. The company has "appointed the firm of PatentBridge LLC, based in Silicon Valley, California, to seek out licensing opportunities in the USA." 48 GTG has also "appointed the London-based law firm of SJ Berwin LLP to support its licensing program in Europe." 49

41. Holmes, "Patently a Problem," supra note 19.

42. Ibid.

43. Genetic Technologies Limited, "GTG Law Suits Against Nuvelo and Covance Now Dismissed" (8 December 2003), <http://www.gtg.com.au/index.asp?menuid=060.070.130.010\&artid=63>

44. Genetic Technologies Limited, "GTG Grants License to LabCorp, of USA" (9 Feburary 2004), <http://www. gtg.com.au/index.asp?menuid=060.070.130.010\&artid=78>.

45. Graeme O’Neill, "GTG firms up O'Connor partnership," Australian Biotechnology News (16 June 2004), <http://www.biotechnews.com.au/index.php?id=1636604791>

46. Genetic Technologies Limited, "GTG Announces Strategic Alliance with MetaMorphix, Inc." (27 February 2006), <http://www.gtg.com.au/index.asp?menuid=060.070.130\&artid=270\&function=NewsArticle>

47. Ibid.

48. Genetic Technologies Limited, "GTG Expands Licensing Programme in USA" (27 January 2006), <http:// www.gtg.com.au/index.asp?menuid=060.070.130\&artid=268\&function=NewsArticle>

49. Genetic Technologies Limited, "GTG Expands Licensing Programme to Europe" (21 February 2006), <http://www.gtg.com.au/index.asp?menuid=060.070.130\&artid=269\&function=NewsArticle>. 


\subsection{Research Licences}

GTG has issued five research licences to a number of universities and public research institutions including the University of Sydney, the University of Technology Sydney, the University of Utah, Colorado University, and King's College.

The University of Sydney became the first research institution in Australia to obtain a research licence from GTG. "The fee of AU\$1,500 charged by [GTG allows] university staff and students to use the so-called junk DNA in basic research for the remaining 15-year duration of the company's patents." 50

Jacobson said that the fee for all the researchers in one institution for fifteen years was a "peppercorn" amount. ${ }^{51}$

The deputy director of the University of Sydney's Business Liaison Office and the Manager of the Intellectual Property and Licensing Unit, Kevin Croft, said that the university was pleased to have negotiated a low-cost deal after being informed by the company that its scientists were infringing the patents. "The mutually beneficial terms of the licence ensure that the university researchers are able to pursue their research with the full support of Genetic Technologies for minimal cost." Mr Croft said the tradition of academics not requiring a research licence in such circumstances had "no law to defend it." 52

In a submission to the ACIP, Croft provided a defence of the University's decision:

While much was made of this in the press and I received a number of comments from researchers at the time, the licence terms, including the fee, were judged not to be onerous or constraining and the existence of the licence provided certainty for a number of researchers..$^{53}$

Croft was of the belief that there was no need for the establishment of a research exemption. He observed that "there appears to be neither need, nor benefit to be achieved, in implementing changes to the patent law that would provide for a significantly more liberal right for non-owners to undertake experiments using patented technologies." 54 Nonetheless, it should be noted that researchers and scientists at the University of Sydney do not share this point of view. It remains to be seen whether other members of the Group of Eight-an elite coterie of Australian universities - will obtain licences in respect of non-coding DNA.

50. Deborah Smith, "DNA Scientists Happy To Buy Junk," The Sydney Morning Herald (4 August 2003), <http://www.smh.com.au/articles/2003/08/03/1059849278757.html>.

51. Ibid.

52. Ibid.

53. Letter from Kevin Croft to Dr Rod Crawford (April 2004), <http://www.acip.gov.au/expusesubs/Kevin\%20

54. Ibid. Croft,\%20Uni\%20of\%20Sydney.pdf>. 
Defending such licensing practices, GTG cites such precedents as the Cohen Boyer patent on recombinant $D^{2} A^{55}$ and the Mullis patent on the polymerase chain reaction (PCR). ${ }^{56}$

GTG cites the decision in Madey v. Duke University to support its contention that educational institutions should enter into licensing agreements for the use of its patented technologies. ${ }^{57}$ It maintains that researchers and scientists are labouring under an erroneous belief that research is exempt from patent claims for infringement:

There is a widespread, but largely erroneous belief that research is somehow exempt from honouring or respecting its obligations under patent law. Interestingly, this misunderstanding is being redressed rather dramatically in the US currently through the case of Madey v. Duke University. In Madey v. Duke University the US Supreme Court clearly indicated that research of the type occurring in almost all academic biomedical labs is not exempt from patent liability. The court noted that to qualify as a pure research use, and thus have a defence against patent infringement, the use would have to be ["]solely for amusement, to satisfy idle curiosity, or for strictly philosophical enquiry"; in other words, the court substantially narrowed the definition of the research that can be regarded as free of a "commercial" flavour. By implication, the vast majority of scientific research occurring in universities, research organisations and not-for-profit institutes would be regarded by the courts broadly as subject to patent liability. ${ }^{58}$

This gloss on the case is not strictly accurate. The US Court of Appeals for the Federal Circuit made the decisive ruling in Madey v. Duke University. The Supreme Court of the United States did not make a judgment on Madey v. Duke University; it refused special leave to appeal. ${ }^{59}$ The implication drawn from the case by GTG is contentious. The Court of Appeals for the Federal Circuit judgment is a United States authority; it may well not be a persuasive precedent

55. For a history of the Cohen-Boyer patent, see Sally Smith Hughes, "Making Dollars Out Of DNA: The First Major Project In Biotechnology And The Commercialization Of Molecular Biology, 1974-1980," (2001) 92:3 Isis 541.

56. For a history of the PCR patent, see Paul Rabinow, Making PCR: A Story of Biotechnology (Chicago: The University of Chicago Press, 1996).

57. Madey v. Duke University, 307 F.3d 1351 (Fed Circ 2002), <http://www.ll.georgetown.edu/federal/judicial/ fed/opinions/01opinions/01-1567.html> [Madey]; for a summary of the debate over patent law and experimental use, see Matthew Rimmer, "The Freedom to Tinker: Patent Law and Experimental Use," (2005) 15:2 Expert Opinion on Therapeutic Patents 167 [Rimmer, "Freedom to Tinker"].

58. Genetic Technologies Limited, "To Medical and Scientific Colleagues" (21 July 2003), <http://www.gtg.com. au/index. asp? menuid $=060.070 .130 .010$ \&artid $=97>$.

59. However, the Supreme Court of the United States did consider the special "Bolar" exemption for pharmaceutical drugs contained in 35 U.S.C. s. 271(e)(1), <http://uscode.house.gov/download/pls/35C28. txt> in Merck KGaA v. Integra Lifesciences I Ltd. et al., 545 U.S. 193, <http://www.supremecourtus.gov/ opinions/04pdf/03-1237.pdf>, 125 S. Ct. 2372 (2005). In a unanimous decision, the Supreme Court held that the safe harbour exempted from infringement all uses of patented compounds reasonably related to the process of developing information for submission under any federal law regulating the manufacture, use, or distribution of drugs. However, the Court declined to address issues with respect to the common law experimental use exemption and the effect of s. 271(e)(1) on research tools (see footnote 7 of the decision). For a commentary on the decision, see Yann Joly, "Integra v. Merck: The Resurrection of the American Research Exemption?" (June 2005). 
in other jurisdictions. ${ }^{60}$ Furthermore, it is presumptuous to conclude that the vast majority of public sector research would be regarded by the courts broadly as subject to patent liability.

In a number of forums, GTG has argued against the establishment of a defence of experimental use. It submitted to the ALRC: "A generic research exemption would totally devalue significant new inventions specifically directed towards assisting research." ${ }^{61}$ GTG argued that it was difficult to draw a boundary between commercial research and pure research:

\begin{abstract}
The question is where does public domain research stop and commercial research start. Whatever the answer is, the border is not the gates of the publicly funded research institutes; these entities are collectively the biggest patenters and licencers in the world. At the end the answer lies in jettisoning the idea of a research exemption and developing a standard form of research licence that would be readily granted by "all" patent holders for a nominal fee, but that would limit coverage to only certain types of activity. Activity beyond this limit would require a commercial licence. ${ }^{62}$
\end{abstract}

GTG noted, "Research organisations do not get their computers free, they do not get software from Microsoft free, nor do they get their chemical lab supplies, staff, space, equipment and utilities free of charge." 63 The company argued that a defence of experimental use would undermine the system of rewards in the patent system for those who invested in research and development. Similarly, the company was opposed to amendments to the Patents Act $1990^{64}$ to include a defence for private, non-commercial use of a patented invention. ${ }^{65}$

Some researchers were sceptical of GTG's claim that it would only charge a "peppercorn" rent of AU $\$ 1,000$ to researchers and research organisations in respect of the patents for non-coding DNA. Robert Cook-Deegan of Duke University commented as follows:

60. Indeed, there is wide variation in the nature and scope of the patent defence of experimental use across jurisdictions. United States jurisprudence does not command universal respect. In Micro Chemicals Ltd. v. Smith Kline \& French Inter-American Corporation, [1972] S.C.R. 506, (1971) 25 D.L.R. (3d) 79, the Supreme Court of Canada held that bona fide experiments with a drug do not constitute patent infringement. The European Union has sought to encourage harmonization amongst its member states in respect of the research exemption under patent law. Article 31 (b) of the Community Patent Convention has provided the basis for an experimental use exception, which exempts "acts done for experimental purposes relating to the subject-matter of the patented invention." Convention for the European patent for the common market (Community Patent Convention (CPC)), 15 December 1975, [1976] O.J.L. 17/1, <http://eur-lex.europa.eu/ LexUriServ/LexUriServ.do?uri=CELEX:41975A3490:EN:HTML>, art. 31(b). German courts have held that the defence of experimental use can apply to both non-commercial and commercial uses, so long as the experimentation is on the patented invention: Klinische Versuche (Clinical Trials) I (Interferon Gamma), [1997] R.P.C. 623 (Fed Sup Ct of Germany) and Klinische Versuche (Clinical Trials) II (Erythropoietin), [1998] R.P.C. 423 (Fed Sup Ct of Germany).

61. Gene Patenting and Human Health," Discussion Paper, supra note 24 at para. 14.108.

62. Ibid. at para. 14.84

63. Ibid. at para. 14.108 .

64. Patents Acts 1990 (Cth), <http://www.comlaw.gov.au/comlaw/Legislation/ActCompilation1.nsf/0/1F75A43C9 34B3201CA2572020013B7D3?OpenDocument> [Patents Act 1990].

65. Gene Patenting and Human Health," Discussion Paper, supra note 24 at para 14.114. 
Why would GTG go after university-based researchers, unless they're planning on doing this with hundreds of universities? If they were doing what most companies do, they would not enforce the patent on universities. Going after universities, and thus increasing costs of research for everyone, is just the sort of thing people are worried about in the wake of Duke v. Madey. If they choose to enforce the patent against companies and universities, the choices are to pay the license fees or try to kill the patent-sign up or take your chances in court. The third option—quietly ignoring the patent-is gone now. ${ }^{66}$

The academic suggested that such a licensing strategy could bolster support for the establishment of a broad statutory exemption for experimental use in the US and elsewhere.

Professor Francis Collins was steadfast that, as a matter of principle, universities should not have to pay licence fees in respect of the non-coding DNA, even if they are for the token amount of $A \cup \$ 1,000$. He feared that "academic researchers will find it very difficult to pursue their best and brightest ideas without a phalanx of lawyers at their elbow and that's really not where we want to go." 67 Collins commented as follows:

I am much more concerned about the company's aggressive licensing strategy. The research exemption, while not codified by law in the U.S., is a tradition that normally protects academic researchers from charges of patent violation, based on the assumption that the public is best served by the free exercise of scientific creativity in the not-for-profit sector. If it turns out that GTG's approach ends up blocking or restricting access to such broadly enabling technology, then that is of great concern to me and the entire genomics community.

I hope that GTG will seriously consider making its invention freely available to anyone who wishes to use it for noncommercial purposes. Saying that the license fee is only a nominal sum is not reassuring-the legal requirements alone will be enough to scare off some users, [and] asking for any license fee at all starts one down a slippery slope toward significant restriction of academic research. ${ }^{68}$

Collins admitted that there was no longer any bright line dividing basic science and applied research. Nonetheless, he maintained that, for the most part, private companies had refrained from bringing patent infringement actions against researchers. Collins observed that exceptional companies who threatened to take legal action against public researchers had received negative feedback: "It has not gone well, there has been an outcry from the scientific community and in fact from most of the private sector as well saying this is not the way to see progress go forward and in those instances ultimately the companies have

66. "Patent's Place," supra note 40.

67. Jonathan Holmes, "Interview with Professor Francis Collins," Four Corners (Australian Broadcasting Corporation, 9 July 2003), transcript, <http://www.abc.net.au/4corners/content/2003/20030811_patent/int_ collins.htm> [Holmes, "Interview with Professor Francis Collins"].

68. "Patent's Place," supra note 40. 
backed off." 69 He would have preferred to see GTG follow the patent and licensing policy in the National Institutes of Health Research Tools guidelines.

\subsection{Cross-Licensing Agreement with Myriad Genetics}

In 2002, GTG approached Myriad in respect of Myriad's activities in intron sequence analysis and genomic mapping. GTG argued that the Utah company needed to obtain a licence if it did not want to infringe GTG's patents.

In response, Myriad brought a lawsuit against GTG in the US District Court for the District of Utah. ${ }^{70}$ The Utah company sought a declaratory judgment of invalidity, unenforceability, and non-infringement with respect to US Patent Nos. 5,612,179 and 5,841,762. Myriad argued that the patents were invalid, void, and unenforceable because the inventions were anticipated and obvious in light of other prior art and because they failed to meet the written description and enablement requirements of the US Patent Act. ${ }^{71}$ It also argued that GTG had made false and misleading statements to the USPTO with respect to issues material to patentability: "GTG, through discriminatory and anti-competitive licensing and attempts to license the patent in that GTG has demanded that Myriad pay licensing fees that are, upon information and belief, grossly out of proportion to the licensing fees paid to GTG by other licensees. "72 Furthermore, Myriad sought a permanent injunction to prevent GTG from "engaging in coercive tactics by threatening to confront Myriad's research collaborators, licensees, and customers with charges of patent infringement."73

Jacobson argued that "the lawsuit was a ploy by Myriad" to obtain a "tactical advantage" during the negotiation of the licence and protect itself in case there was a breakdown in the negotiations. ${ }^{74}$

In the end, the claim was withdrawn without prejudice before the case ever got to the courtroom. Myriad paid US\$1 million plus for licences to GTG's key non-coding DNA analysis patents, and GTG and Myriad agreed that GTG would be Myriad's exlusive marketing agent in Australia and New Zealand for Myriad's medical diagnostics. ${ }^{75}$ The press release observed the following:

Under the terms of the agreement, Myriad will receive a broad, non-exclusive license to Genetic Technologies' non-coding DNA analysis and mapping patents for all applications in human therapeutics and diagnostics. Genetic Technologies will become Myriad's exclusive marketing agent in Australia and New Zealand for its world-leading predictive medicine products for a range of important diseases, including breast cancer, ovarian cancer, colon cancer, melanoma and hypertension. The testing for the breast and ovarian cancer

69. Holmes, "Interview with Professor Francis Collins," supra note 67

70. Complaint for Declaratory Judgment and Permanent Injunction, Myriad Genetics Inc. v. Genetic Technologies Limited, Civil No.: 2_02 CV-0964 BSJ (D Utah, filed 26 August 2002), 2002 WL 33950375 [Myriad Complaint]

71. Patent Act, 35 U.S.C. (2000), <http://uscode.house.gov/download/title_35.shtml>

72. Myriad Complaint, supra note 70 at para. 28

73. Ibid. at para. 44

74. Melissa Trudinger, "GTG suing Applera, Covance over patent infringement," Australian Biotechnology News (11 September 2003), <http://www.biotechnews.com.au/index.php?id=1871349860>

75. Genetic Technologies Limited, "Genetic Technologies and Myriad Genetics Announce Strategic Licensing Agreement" (28 October 2002), <http://www.gtg.com.au/index.asp?menuid=060.070.130.010\&artid=126>. 
will be offered through Genetic Technologies' state-of-the-art testing facilities in Melbourne, Australia. The other predictive medicine products will be performed by Myriad in its laboratory in the United States. Myriad has granted Genetic Technologies an option to perform the other tests in Melbourne upon future payment of agreed fees and royalties. ${ }^{76}$

After the announcement of this cross-licensing deal, GTG stressed that it was the only lawful provider of genetic testing held by Myriad in Australia. It emphasized that other service providers were guilty of patent infringement. Jacobson said genetic tests available in Australia at the time were being provided by "'entities who have chosen to set up without any license or approval' of the patent owner." 77 He observed, "[u]nder the law, if it's patented and you use it without the licence, it is patent infringement, it's breaking the law."78

Following the cross-licensing deal, the public affairs program 60 Minutes aired a critical program on GTG called "The Profit Motive."79 The episode generated dismay and concern among the wider public. In response, GTG announced that it would not enforce the patents on BRCA1 and BRCA2 in Australia. A press release said,

GTG also announced that the intellectual property rights it had obtained from Myriad for breast cancer susceptibility testing will not be enforced by GTG against other service providers in Australia and New Zealand-and were a gift from GTG to the people of Australia and New Zealand. ${ }^{80}$

The ALRC suggested that the company has now been estopped from taking legal action because of its public statements. ${ }^{81}$

However, there remains some ambiguity about the status of this "gift." GTG is only the exclusive licensee of the genetic tests in respect of breast cancer and ovarian cancer. Although the Melbourne company can certainly decide not to enforce the patents, it cannot bind the patent owner, Myriad Genetics. The Utah biotechnology company has not made any public undertakings that it will not enforce the patents in the context of Australia and New Zealand. It is possible that Myriad might still bring legal action for patent infringement in those jurisdictions. In any case, it should be recalled that the patents held by Myriad may be invalidated in legal proceedings. Ultimately, GTG and Myriad might not be in a position to "gift" BRCA1 and BRCA2; such genes could become global public goods.

Moreover, the Four Corners report revealed that GTG will still be seeking royalties in respect of the use of its non-coding DNA patents. Dr Graeme Suthers observes that the company has encumbered the "gift" with hidden costs:

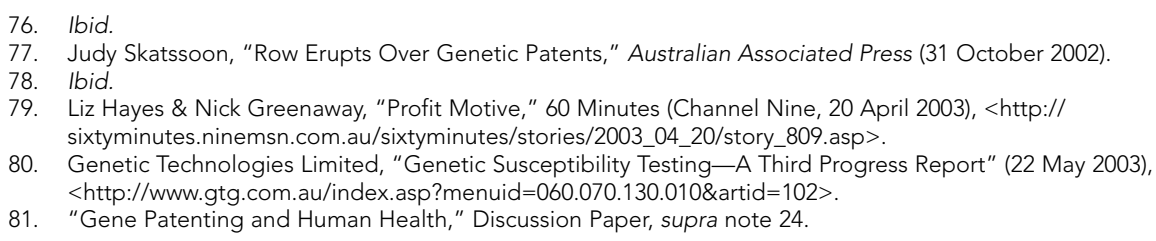


I've got mixed feelings about that. Because it may be that GTG has provided a generous gift of the BRACA [sic, BRCA] licences to the Australian people. But they will take it back with the other hand by asking for licence fees for the non-coding patents which are essential for doing the [BRCA] analyses..$^{82}$

Furthermore, the costs associated with the use of the non-coding DNA patents are not the "peppercorn rents" GTG would like to suggest. A freedom-ofinformation application revealed that the company was seeking substantial sums from the New Zealand Government for the use of the non-coding DNA patents. ${ }^{83}$ Of course, this could have just been an ambit claim on the part of GTG. There is no evidence that this agreement has been finalized.

There are a number of possibilities why GTG decided to change tack and make public utterances that BRCA1 and BRCA2 would be given to the Australian public as a gift. Of course, it is difficult to second-guess internal corporate decisions. Nonetheless, it is worthwhile to speculate why there was a volte-face on the part of the company. GTG might have been concerned about the public backlash after the media report aired on 60 Minutes. They could have decided to avoid further controversy over the particularly sensitive topic of breast cancer and ovarian cancer. It is possible that GTG could have been concerned about the legal challenges to the patents related to BRCA1 and BRCA2. The company may have decided that it would have a firmer legal position if they relied instead upon the non-coding DNA patents. Through making a gift of BRCA1 and BRCA2, GTG improved its bargaining position in the policy debate over gene patents and human health. The decision not to enforce the patents related to BRCA1 and BRCA2 would have strengthened the company's defence of the status quo.

\subsection{Patent Revocation}

In Europe, Myriad has recently suffered several setbacks. The European Patent Office has revoked one of its patents dealing with BRCA1, narrowed the scope of a couple of its patents dealing with BRCA1, and awarded Michael Stratton and Cancer Research UK a patent dealing with BRCA2. ${ }^{84}$ Myriad may well appeal against such decisions and may also rely upon its licence from GTG to commercialize the patents with respect to non-coding DNA.

82. Holmes, "Patently a Problem," supra note 19.

83. Ibid.

84. The Institut Curie and its supporters have challenged Myriad Genetics' patents: EP 699754 (which was revoked), EP 705902 and EP 705903 (whose claims were narrowed), and EP 785216 (the patent relating to BRCA2). Myriad Genetics has transferred some of its rights to the University of Utah Research Foundation. See Matthew Rimmer, "Myriad Genetics: Patent Law And Genetic Testing," (2003) 25:1 European Intellectual Property Review 20; Andy Coghlan, "Europe revokes controversial gene patent," New Scientist (19 May 2004), <http://www.newscientist.com/article/dn5016.html>; Andrew Pollack, "Patent on Test for Cancer Is Revoked By Europe," The New York Times 3 (19 May 2004) <http://query.nytimes.com/gst/fullpage.html?sec=health\&re s=9C01E7D6123FF93AA25756C0A9629C8B63>; Institut Curie, "The European Patent Office has revoked the Myriad patent," Press Release (21 May 2004), <http://www.curie.fr/upload/presse/190504_gb.pdf>; Cancer Research UK, "Charity to make breast cancer (BRCA2) gene freely available across Europe," Press Release (11 February 2004), <http://info.cancerresearchuk.org/news/pressreleases/2004/february/38944>; Susan Mayor, "Charity wins BRCA2 patent," The Scientist (13 February 2004), <http://genomebiology.com/researchnews/ default.asp?arx_id=gb-spotlight-20040213-01>; European Patent Office, "Public opposition hearings on two genetic engineering patents ("breast cancer gene") at the European Patent Office" (17 January 2005), <http://www.epo.org/about-us/press/releases/archive/2005/17012005.html>. 
GTG has been understandably anxious about the revocation of the patent held by Myriad in the European Union. ${ }^{85}$ Jacobson was quick to reassure the stock market that the decision of the EPO did not have any financial ramifications for the Melbourne company. He argued that the opposition to the patent held by Myriad was misconceived because it was based upon policy concerns about research and health care: "Another group of community organisations also filed, but its case was based more on concerns about the company's attitude-its corporate style and its costing structure for the test." 86 This gloss on the panel decision of the EPO seems somewhat hasty and misconceived. The Institut Curie and its allies had opposed the patent of Myriad on formal grounds of criteria such as novelty, inventive step, and written description. ${ }^{87}$ It is inaccurate to claim that their concerns were policy objections. Furthermore, the managing director of GTG was not in a good position to second guess the decision of the EPO, because it had not handed down its written decision at the time of the comments.

Jacobson stressed that the decision does not affect Myriad's two other European patents on the BRCA1 test, and he expressed confidence that Myriad could win an appeal against the panel decision of the European Union. He argued that, in any case, Myriad could rely upon its licence to commercialize the patents with respect to non-coding DNA. Jacobson observes the following:

\footnotetext{
It may well be that Myriad is appreciative of having access to patents like ours. It may well be that their plans in Europe are dependent to some degree on our support for their parents [sic, patents]. It's just an example of the need to be incredibly stringent in following the rules precisely, which is what we have done with our patents. ${ }^{88}$
}

Thus, Myriad has a fall-back position, in the event that it loses an appeal in the EPO. Under its agreement with GTG, it has the right to commercialise GTG's non-coding DNA patents in Europe, at least as they apply to the BRCA1 and BRCA2 genes.

\section{* \\ 3. JUNKYARD DOGS: GENETIC TECHNOLOGIES LIMITED V. APPLERA CORPORATION}

ON 26 MARCH 2003, GTG FILED A PATENT INFRINGEMENT ACTION in the US District Court for the Northern District of California against the major life sciences company, Applera, and its subsidiaries: Applied Biosystems Group, the Celera

85. Graeme O'Neill, "How Myriad's GCAT got out of the bag," Australian Biotechnology News (21 June 2004), <http://www.biotechnews.com.au/index.php?id=202026907> [O'Neil, "GCAT out of the bag"]; Graeme O'Neill, "EU patent snatchback won't affect GTG: Jacobson," Australian Biotechnology News (21 May 2004), <http://www.biotechnews.com.au/index.php?id=213369704>

86. O'Neil, "GCAT out of the bag," ibid.

87. Institut Curie, "The Institut Curie, the Assistance Publique-Hôpitaux de Paris and the Institut Gustave-Roussy file a joint opposition notice to the Myriad Genetics patent with the European Patent Office," Press Release (10 October, 2001), <http://www.curie.fr/upload/presse/myriadopposition10oct01_gb.pdf>.

88. O'Neil, "GCAT out of the bag," supra note 85. 
Genomics Group, and Celera Diagnostics. ${ }^{89}$ The complaint alleged that the companies were infringing US Patent No. 5,612,179, entitled "Intron Sequence Analysis Method for Detection of Adjacent and Remote Locus Alleles as Haplotypes." 90 The allegedly infringing products were cystic fibrosis reagent kits sold through Celera Diagnostics, and products "relating to methods of analysis of non-coding sequence variants."91 The complaint also alleged that the companies in the Applera Group were infringing US Patent No. 5,851,762. ${ }^{92}$ GTG sought "monetary damages, costs, expenses, injunctive relief, and other relief as the court deems proper." 93

\title{
3.1. Applera Activities
}

Applera was a troublesome and tenacious adversary for GTG. As a large, wellresourced biotechnology company with substantial legal expertise, it had great experience in filing, prosecuting, and litigating patents. ${ }^{94}$

Applera and its subsidiaries have accumulated a large number of patents. Applied Biosystems has obtained 700 patents and has another 1,200 patents pending in jurisdictions around the world. ${ }^{95}$ In an amicus curiae brief in the Festo case, the counsel for Applera acknowledged the following:

\begin{abstract}
As a leader in the biotechnology field, Applera operates in a technologically dense environment. Not surprisingly, patent rights play an important role in its businesses. To be clear, Applera holds key patent rights and has been, and is, involved in litigation where it is the patent-holder. Likewise, as a successful company with substantial market share, Applera is the target of patent claims and has been, and is involved in litigation where it is the accused infringer. Applera merely seeks clear and certain rules that encourage and reward innovation by reinforcing the respect for legitimate patent rights, while also ensuring that the scope of the patent rights of others is clear to those wishing to enter or advance in a particular field. 96
\end{abstract}

Applera has been a stout enforcer of its patents. The corporate group spent US\$17.6 million on legal fees in the first nine months of 2004. ${ }^{97}$ "'They're not shrinking violets,' said a lawyer who worked with them." 98 The corporate group

89. First Amended Complaint for Patent Infringement, Genetic Technologies Limited v. Applera Corporation, No. C-03-1316 PJH (ND Cal, 11 August 2003), 2003 WL 23796523 [GTG, First Amended Complaint for Patent Infringement].

90. Ibid.

91. Ibid. at Introduction.

92. "Genomic mapping method" patent, supra note 6.

93. Securities and Exchange Commission, "Quarterly Report Pursuant to Section 13 or 15(d) of the Securities Exchange Act of 1934 for the quarterly period ended March 31, 2003 for Applera Corporation" (Washington, DC: March 2003), <http://media.corporate-ir.net/media_files/NYS/ABI/reports/10q_q3_2003. pdf $>$ at p. 16

94. Ibid. at p. 14.

95. Alan Cohen, "Going, Going...," (2004) 4:7 IP Law and Business 30 [Cohen, "Going, Going..."].

96. Brief of Amicus Curiae Applera Corporation in support of the respondents, Festo Corporation v. Shoketsu Kinzoku Kogyo Kabushiki Co Ltd, <http://latimes.findlaw.com/supreme_court/briefs/00-1543/00-1543.pet. ami.applera.pdf> at p. 1.

97. Cohen, "Going, Going...," supra note 95

98. Ibid 
has been the subject of a number of patent lawsuits. ${ }^{99}$ Applera recognized the risks associated with such litigation in an annual report: "There has been substantial litigation regarding patents and other intellectual property rights in the biotechnology and pharmaceutical industries." 100

In its complaint, GTG detailed a number of allegedly infringing activities on the part of the Applera Corporation. First, the Applera Genome Initiative is engaged in the identification and selection of approximately 200,000 SNPs located in genes or gene-regulatory regions, and the validation of approximately 90 sets of human DNA, by generating individual genotypes and allele frequency data. ${ }^{101}$ The Initiative compares genotypes and gene expression profiles from healthy and diseased populations to identify and validate new markers for incorporation into molecular diagnostic tests. It also provides a framework for the haplotype map of the human genome. GTG alleged that such activities fall within the scope of its patents.

Second, Applied Biosystems develops and markets instrument-based systems, reagents, software, and contract services to the life science industry and research community. Commercial products include the Assays-on-Demand SNP Genotyping kits, the Assays-by-Design SNP Genotyping kits, and the Celera Discovery System. GTG argues that such products involve the use of non-coding DNA with such conduct falling within the scope of its patents: "Use of the Assays-on-Demand SNP Genotyping kits and the Assays-by-Design SNP Genotyping kits involves amplification of genomic DNA with primer pairs." 102

Third, Celera Diagnostics is involved in the discovery, development, and commercialization of diagnostic products. One of the commercial molecular diagnostic test products offered for sale is the Cystic Fibrosis ASR product. GTG alleged, "Several of the mutations or polymorphisms tested by the Cystic Fibrosis ASR kit are non-coding sequence variants that are characteristic of one or more coding region alleles of the Cystic Fibrosis locus." 103 Celera Diagnostics is also collaborating in the study of genes for use in the diagnosis and treatment of a variety of diseases. This project includes analysis of genetic variation associated with approximately 1,000 SNPs in over 3,000 clinically defined samples. Celera Diagnostics is also engaged in research to establish the clinical utility of laboratory tests based on diagnostic markers for a variety of diseases and cancers. Such tests relate to cardiovascular disease, diabetes, Alzheimer's disease, breast cancer, and prostate cancer.

Fourth, Applera and its operating divisions are involved in commercial relationships to detect, identify, and determine the chromosomal locations of various genes associated with one or more traits. Such research includes work on disease genes, drug responsiveness genes, drug susceptibility genes, and quality trait loci. GTG alleged that "at least some of the studies involve the use of haplotyping to compare the haplotypes exhibited by a trait-bearing population

99. Applera's lawsuits have involved shareholders, competitor companies, and inventors who claim ownership of patents awarded to Applera or its subsidiaries. Applera Corporation, 2005 Annual Report, <http://www. applera.com/annualreports/annual2005/AppleraAR05.pdf $>$ at pp. 22, 29, 63, 72-74.

100. Applera Corporation, 2003 Annual Report, <http://www.applera.com/annualreports/annual2003/2003_ Applera_AR_lowres.pdf $>$ at p. 49.

101. GTG, First Amended Complaint for Patent Infringement, supra note 89

102. Ibid. at para. 14 .

103. Ibid. at para. 17. 
versus a general (control) population at multiple chromosomal regions." ${ }^{104}$ Again, the Melbourne company asserted that such activities come within the scope of its patents.

Finally, Celera Genomics is engaged in integrated advanced technologies to discover and develop new therapeutics by leveraging its capabilities in proteomics, bioinformatics, and genomics to identify and validate novel drug targets and to discover novel therapeutic candidates. GTG is concerned that Celera Genomics participates in the commercialisation of diagnostic products based on its discoveries through Celera Diagnostics.

\subsection{Patent Infringement}

GTG claimed that Applera has engaged in a number of activities which fall within the scope of US patent $5,612,179$ :

Upon information and belief, Applera has designed, tested, manufactured, marketed, offered to sell, and sold its products and/or services, including, but not limited to the Cystic Fibrosis ASR kit, the Assays-on-DemandTM SNP Genotyping kits, the Assays-by-DesignSM SNP Genotyping kits, and the Celera Discovery System. ${ }^{105}$

Furthermore, the company argued: "Upon information and belief, Applera has engaged in activities within the scope of the Applera Genome Initiative with full knowledge of the claims of the US patent 5,612,179, and with full knowledge of GTG's rights therein." 106

Similarly, GTG argued that Applera had engaged in a number of activities that fall within the scope of US patent $5,851,762$. It submitted that Applera had infringed the patent by undertaking activities in genomic haplotype analysis, including

creating a haplotype map of the human genome; creating a haplotype map of the mouse genome; creating haplotype maps of genomic DNA of species other than mouse or human; and obtaining genomic DNA samples from individuals exhibiting a range of traits. ${ }^{107}$

Consequently, GTG argued that

Applera has designed, developed, tested, manufactured, marketed and used certain products and/or services relating to haplotype analysis of genomic DNA with full knowledge of the claims of the US patent $5,851,762$, and with full knowledge of GTG's rights therein. ${ }^{108}$ 
In its first claim of relief, GTG alleged that Applera has engaged in direct infringement of its patent rights in both the 5,612, 179 and the 5,851,762 patents. ${ }^{109}$ The company observed:

Applera has developed, tested, manufactured, marketed, offered for sale, sold, and continues to develop, test, manufacture, market, offer for sale and sell certain products and/or services that infringe GTG's rights in both the $5,612,179$ and the 5,851,762 patents. Applera's direct infringement of both the 5,612, 179 and the 5,851,762 Patents has been with full knowledge of GTG's rights therein. ${ }^{110}$

GTG claims that it is suffering "irreparable harm" as a result of Applera's continuing direct infringement of both the 5,612,179 and the 5,851,762 patents. ${ }^{111}$

In its second claim of relief, GTG asserts that Applera has induced third parties to infringe both patents ${ }^{112}$ in that it "has offered training, instruction or other advice to its customers, licensees or others in the use of its products and technology, including but not limited to the Cystic Fibrosis ASR kit," the Assayson-Demand ${ }^{T M}$ SNP Genotyping kits, the Assays-by-Design ${ }^{\text {SM }}$ SNP Genotyping kits, and the Celera Discovery System. ${ }^{113}$ It maintains that the alleged inducement of patent infringement was both "wilful and malicious." 114

In its third claim of relief, GTG further claims that Applera has been engaged in contributory patent infringement ${ }^{115}$ in having "manufactured, offered for sale, and sold certain products and/or services" that "constitute a material part of the inventions claimed in the "179 Patent."116 It argued that "Applera's products and/or services relating to non-coding sequence variation detection and haplotype analysis and the methods of their use are not staples of industry, and they are not commodities suitable for substantial non-infringing use."117 It concluded: "As a result of Applera's development, testing, manufacture and/or sale of its products and/or services, and as a result of its instruction, training or advice in the use of such products and/or services, Applera has contributorily infringed GTG's rights in the "179 Patent."118 It insisted that such contributory patent infringement was both "wilful and malicious."119

GTG has sought preliminary and permanent injunctions barring Applera from engaging in all of these allegedly infringing activities. In addition to costs, GTG sought damages "in no event less than a reasonable royalty to GTG for the rights secured in both the "179 and the "762 Patents" and "treble damages in

109. Ibid. at paras. 34,35 .

110. Ibid. at paras. 39,40

111. Ibid. at para. 44 .

112. Complaint for Patent Infringement, Genetic Technologies Limited v. Applera Corporation, No. C 03-1316 (ND Cal, 26 March 2003), 2003 WL 23794369 [GTG, Complaint for Patent Infringement].

113. Ibid. at para. 29 .

114. Ibid. at para. 35 .

115. GTG, First Amended Complaint for Patent Infringement, supra note 89

116. Ibid. at para. 55 .

117. Ibid. at para. 57

118. Ibid. at para. 58 .

119. Ibid. at para. 61 
compensation for the exceptional circumstances of Applera's infringement." 120

\title{
3.3. Answer and Counterclaims
}

In response, Applera put forward a number of affirmative defences to the claims of GTG. ${ }^{121}$ Foremost, it declared that Applera had not infringed, and was not infringing, either patent. Further, it alleged that both patents failed to comply with the requirements of the US Patent Laws, including lack of novelty, inventive step, and problems with the written specifications. ${ }^{122}$

Applera argued that the patents of GTG were invalid because they were anticipated and obvious in light of prior art. The company identified a range of prior art, which it alleged anticipated the patent applications filed by GTG. ${ }^{123}$ The company observed the following:

\begin{abstract}
At least as early as 1978, researchers began publishing RFLP studies showing correlations between non-coding DNA sequence variations and diseaserelated coding sequence variations. With the advent of PCR in the mid-1980's, many more researchers published such correlations and described them in patents. Some of these references did not go unnoticed by the PTO. Contrary to GTG's representation in its Opening Brief, others had clearly recognized prior to GTG's alleged "discovery" that non-coding regions contained significant, useful information. [...] Accordingly, GTG was forced to disclaim any patent coverage for "occasional," "empirically-determined" correlations of particular intron sequence polymorphisms with particular coding region variations. This disclaimer is further discussed below.
\end{abstract}

By the time GTG filed its first patent application, other researchers had applied non-coding sequence analyses to the 13-thalassemia, apolipoprotien $B$, and phenylalanine hydroxylase genes. Indeed, at least one researcher suggested that "any coding gene, defective or normal, will be surrounded by a unique set of DNA polymorphisms," and another observed that if noncoding gene regions are not conserved, "[i]t should be thus possible to derive

120. Ibid., "Prayer for Relief."

121. Answer and Counterclaims of defendant Applera Corporation, Genetic Technologies Limited v. Applera Corporation, No. C-03-01316 PJH (ND Cal, 5 September 2003), 2003 WL 23794380 [Applera, Answer and Counterclaims].

122. 35 U.S.C. ss. 102, 103, 112 (2004), <http://uscode.house.gov/download/title_35.shtml>.

123. Exhibit A refers to Yuet Kan, and Andree Dozy, "Polymorphism of DNA Sequence Adjacent to Human BetaGlobin Structural Gene: Relationship to Sickle Mutation," (1978) 75:11 Proceedings of the National Academy of Sciences 5631, <http://www.pnas.org/cgi/reprint/75/11/5631>; Exhibit B refers to United States Patent No. 4,683,202 to Mullis (the inventor of PCR) <http://patimg1.uspto.gov/. piw?Docid=04683202\&idkey=NONE>; Exhibit C refers to Jurgen Geisel et al., "A New APA LI Restriction Fragment Length Polymorphism in the Low 28 Density Lipoprotein Receptor Gene," (1988) 26:7 Journal of Clinical Chemistry and Clinical Biochemistry 429; Exhibition D concerns Peter Little et al. "Model for Antenatal Diagnosis of Beta-thalassaemia and Other Monogenic Disorders by Molecular Analysis of Linked DNA Polymorphisms," (1980) 285:5761 Nature 144 [Little et al., "Model for Antenatal Diagnosis of Betathalassaemia"]; Exhibit E is John Guardiola et al., "Molecular Genotyping of the HLA-DQ [_] Gene Region," (1988) 27:1 Immunogenetics 12. 
from the non-coding and flanking regions of the HLA-DQa gene probes capable of distinguishing a specific allogenotype in the presence of another." These references were not before the PTO Examiner during the prosecution of GTG's patents. ${ }^{124}$

In addition, Applera asserted that, by reason of the proceedings in the USPTO during prosecution of the applications that resulted in the issuance of both patents, "GTG is estopped from asserting any construction of the claims of the patent which would cover or include any of the purported acts of infringement of which GTG complains." 125 Finally, Applera argued that the claims of GTG were barred by the defence of laches. The company sought declaratory judgments of non-infringement and invalidity of both patents.

There has been great debate over the validity and the scope of the patents held by GTG, especially in terms of their novelty and inventiveness. Mervyn Jacobson of GTG contends that the patents are novel, non-obvious, and useful. ${ }^{126} \mathrm{He}$ maintains that this view is supported by a number of testimonials from famous scientists:

\begin{abstract}
In fact going back historically, when we first published our work in the early 90 s, the journal that published it chose to actually have an editorial commendation on the importance of our invention and the innovation of Malcolm Simons at the time-it was particularly noted as a worthy invention. Further, when we moved from just the one narrow field of HLA to more broadly, other human genes, animal genes, plant genes, we were supported by scientists around the world, including world leading eminent scientists like Professor Leroy Hood of the University of Washington in Seattle who wrote a testimonial, that this was totally unexpected and novel to him and should be patented, it was also supported by Professor Peter Gresshoff of the University of Tennessee at the time and an expert in plant genetics who made a similar comment... [and] by Dr Pablo Rubenstein of the New York Blood Centre and a number of scientists at that time who said this indeed is novel, this is unexpected. ${ }^{127}$
\end{abstract}

Jacobson claimed that the research on non-coding DNA by Malcolm Simons was breakthrough science. He argued that geneticists failed to appreciate the significance of the work performed by immunologists.

[T] he HLA experts had their own conferences and don't particularly meet with other human geneticists, who don't meet with the other animal geneticists, who don't meet at conferences with plant geneticists-in fact they even use different language, the nomenclature, they use words differently, it's almost like they're on different planets. ${ }^{128}$

124. Applera Corporation's Claim Construction Brief, Genetic Technologies Limited v Applera Corporation, No. C 03-01316 (PJH) (ND Cal, 30 July 2004), 2003 WL 23794399 at part B.

125. Applera, Answer and Counterclaims, supra note 121 at para 67.

126. Jonathan Holmes, "Interview with Dr Mervyn Jacobson," supra note 29.

127. Ibid.

128. Ibid. 
GTG has only quoted selectively from such expert testimony in its public relations. ${ }^{129}$ In July 1993, Professor Leroy Hood provided a testimonial in respect of the patents held by Malcolm Simons: "This observation was a great surprise to me." ${ }^{130}$ His own data indicated, "the presence of informative polymorphisms in non-coding regions of these 'vastly different types of genes'"131 in a range of species. He concluded that "these informative polymorphisms, which are indicative of haplotypes and alleles, are 'present throughout the eukaryotic genome'."132 In February 1992, Professor Peter Gresshoff commented that Simons work was unexpected: "Simons' data may indicate that recombination within functional regions is suppressed, and occurs only at 'hotspots' at the end of a transcriptional unit, a genetic focus." 133 Professor Pablo Rubinstein described Simons' work as "totally unexpected." 134 He said, "There was no reason, a priori, to believe that introns would be informative in this regard." He further stated that "there was no reason to expect that Simons' data relating to the HLA system would be 'an isolated curiosity of nature' -it could be reasonably expected that the same principles would govern the evolution of alleles in other multi-allelic gene families." 135 Dr Brian Tait wrote in February 1992: "The state of the art at the time of Malcolm Simons' invention was that introns and other non-coding regions were thought to be fairly random DNA arrangements." $136 \mathrm{He}$ observed: "However, we did not recognise that the non-coding region polymorphisms generally were sufficiently conserved to provide a complete typing system." 137 He described Simons' ideas as "'a significant advance' that could be used on a daily basis in the laboratory to type alleles." ${ }^{138}$ The company was reluctant to publicly release such expert testimony in full in the course of the legal proceedings with Applera. ${ }^{139}$ The quality and credibility of such expert evidence would have an important bearing on the determination of the patents' validity.

Malcolm Simons and his friend the patent attorney, Carol Nottenburg, argue that the patents are indeed novel and inventive, but have expressed reservations about the scope of the claims asserted by GTG. ${ }^{140}$ The original inventor has issued a clarification concerning his view of the non-coding DNA patents. ${ }^{141} \mathrm{He}$ sought to dispel some of the misconceptions about his research: "It has become obvious to me that the disbelief in, and reactions to, the patents mainly arise from imprecision in the wording of the patent claims, and from a failure to clearly distinguish my discoveries and inventions from prior art." 142 Simons comments on the relationship of his research to the prior art:

129. Graeme O’Neill, "Prior Art," Australian Biotechnology News (22 August 2003) 8.

130. Ibid

131. Ibid.

132. Ibid.

133. Ibid.

134. Ibid.

135. Ibid.

136. Ibid.

137. Ibid.

138. Ibid.

139. Plaintiff's Opening Construction Brief, Genetic Technologies Limited v. Applera Corporation, No. C-03-1316 PJH (ND Cal, 16 July 2004), 2003 WL 23796524

140. Malcolm Simons, "'Junk DNA' Non-Coding DNA Patents: The Inventors' View," Simons Haplomics (18 May 2004), <http://www.simonsjunkdna.com/Full\%20Article.htm> [Simons, "The Inventors' View"]; and Carol Nottenburg \& Jade Sharples, "Analysis of 'Junk DNA' Patents," Simons Haplomics (July 2004), <http://www. simonsjunkdna.com/junk\%20dna\%20analysis.pdf>.

141. Simons, "The Inventors' View," ibid.

142. Ibid. 
To my knowledge, all current DNA Diagnostic test performed on non-coding sequences can be considered in two categories:

(1) mutation (alternative splice site) testing: where the site is investigated for its inherent information, as in the CFTR, beta-globin and PAH genes;

(2) marker (haplotype) tagging: where non-coding sequence analysis is used to characterize haplotypes in pedigree analysis, by linkage.

The first category is not taught by the Patent since there is no coding sequence allele in linkage with the site being tested. The non-coding site cannot be in linkage with itself. Furthermore, the PAH gene report was recognized as prior art in the Intron Diagnostic patent.

The second category was argued in the patent prosecution history to be prior art. The earliest examples are the reports in 1978 by Kan and Dozy $(1,2)$. Amplification of prior-known RFLP sites as an obvious simplification of previous linkage carrier detection was also recognized in the Intron Diagnostic patent as prior art $(11,12)$.

I am unaware of any current DNA molecular laboratory test for diseaseassociated gene diagnostics, or for HLA typing, that utilizes the method of the Intron Diagnostic patent.

By contrast, all uses of population-based LD / Allele association fine-mapping seem to me to be encompassed by the Genome Mapping patent. ${ }^{143}$

Thus, Simons has also expressed reservations about the breadth of the patent claims made by GTG. Indeed, the morning after the Four Corners report, the scientist appeared on Nine's Today program to protest GTG's behaviour. The immunologist told Forbes that he was "willing to take the stand for either side to clarify the patent if the Applera lawsuit goes to trial."144 The inventor, therefore, is something of a maverick. He is an unpredictable, uncertain element in the whole controversy.

By contrast, a number of researchers and scientists were sceptical of the inventiveness of the patents, finding the broad claims to be dubious. Members of the public Human Genome Project have expressed doubts about the validity and the scope of the patents. Francis Collins was surprised that the patent office had granted patents to GTG in respect of non-coding DNA:

I personally find it surprising that the GTG patent was issued, given the requirements of the PTO's (US Patent and Trademark Office's) novelty, nonobviousness, and utility standard. After all, there were many prior published reports on the correlation of variation in noncoding regions with important mutations, going back at least to Kan and Dozy's The Lancet report on the sickle mutation back in 1978. But the validity of the patent is something for the attorneys, the PTO, and the courts, to weigh in on-not me. ${ }^{145}$

\footnotetext{
143. Ibid.

144. Zina Moukheiber, "Junkyard Dogs," Forbes (29 September 2003), <http://www.forbes.com/ forbes/2003/0929/052_print.html> at p. 2.

145. "Patent's Place," supra note 40.
} 
Nobel Laureate Sir John Sulston was sceptical of the portrayal of Simons as "the genius of junk." He observed, "the generality that there are very important sequences outside the narrow specific protein coating bits was well known throughout the $80 \mathrm{s.}$ " 146 Sulston argues that the scope of the patent is of particular concern: "What he cannot possibly be justified in doing at that time is claiming all of the non-coding sequence in all organisms." 147 Martin Bobrow of Cambridge University argued that the patents were a sign that biotechnology patents were too easy to obtain and that the rules governing patentability needed to be tightened: "Broad patents that lead to extraordinarily large rewards for extraordinarily little inventive input are a wholly destructive trend."148

A number of Australian and New Zealand geneticists entered the debate about the patents relating to non-coding DNA and genomic mapping. Professor John Mattick of the Institute of Molecular Biosciences was concerned that the Catalyst program gave the misleading impression that his work vindicated Malcolm Simons' claims to inventive insights about non-coding sequences. ${ }^{149} \mathrm{He}$ expressed his views that the patents were lacking in novelty and inventive step on the Four Corners program. ${ }^{150}$ Professor Peter Little of the University of New South Wales doubted GTG's claim that its principals made important discoveries concerning the nature of "junk" DNA that were not appreciated in 1989 by the scientific community. ${ }^{151} \mathrm{He}$ observed the following:

It is unclear to me why, in 1989, it was necessary to prove the idea that linked polymorphisms could be used to analyse functional variation: The fundamental principles and practice had been widely published, and these could be simply applied to any gene, including the HLA complex. Importantly, the concepts of haplotypes, linkage disequilibrium, and linkage had all been identified as directly relevant to the DNA-based analyses then available.

146. Jonathan Holmes, "Interview with Sir John Sulston," Four Corners (Australian Broadcasting Corporation, 9 July 2003), transcript, <http://www.abc.net.au/4corners/content/2003/20030811_patent/int_sulston.htm> [Holmes, "Interview with Sir John Sulston"].

147. Ibid

148. Rachel Nowak \& David Concar, "Footing The Bill: Should We All Have To Pay For One Company's Bright Idea," New Scientist 4 (18 May 2002) at p. 5.

149. "Genius of Junk (DNA)," supra note 1.

150. Jonathan Holmes, "Interview with Professor John Mattick," Four Corners (Australian Broadcasting Corporation, 10 July 2003), transcript, <http://www.abc.net.au/4corners/content/2003/20030811_patent/int_ mattick.htm> [Holmes, "Interview with Professor John Mattick"].

151. Peter Little, "GTG's Inventions Concerning 'Junk' DNA," Bio-IT World (11 September 2003), <http://www. bio-itworld.com/archive/091103/letters.html> [Little, "GTG's Inventions Concerning 'Junk' DNA"]. Little cites a number of publications as prior art, including: Yuet Kan \& Andee Dozy, "Antenatal Diagnosis of Sickle-Cell Anaemia by D.N.A. Analysis of Amniotic-fluid Cells," (1978) 2 Lancet 910; Yuet Kan, \& Andree Dozy, "Polymorphism of DNA Sequence Adjacent to Human Beta-Globin Structural Gene: Relationship to Sickle Mutation," (1978) 75:11 Proceedings of the National Academy of Sciences 5631, <http://www. pubmedcentral.nih.gov/articlerender.fcgi?artid=393021 >; Little et al., "Model for Antenatal Diagnosis of Beta-thalassaemia," supra note 123; John Phillips, et al. "Prenatal Diagnosis of Sickle Cell Anemia by Restriction and Endonuclease Analysis: Hind III Polymorphisms in Gamma-Globin Genes Extend Test Applicability," (1980) 77:5 Proceedings of the National Academy of Sciences 2853, <http://www. pubmedcentral.nih.gov/articlerender.fcgi?artid=349503>; and David Botstein et al. "Construction of a Genetic Linkage Map in Man Using Restriction Fragment Length Polymorphisms," (1980) 32:3 American Journal of Human Genetics 314. 
GTG's contention that its principals had discovered something that was "largely overlooked" is not supported by the scientific literature. The comment that non-genic DNA is "a valuable and highly ordered reservoir of useful genetic information" is simply a restatement of what was first demonstrated in 1978 and applied widely. In this strict sense, such DNA can never be truly "junk" by virtue of its linkage to genes and must always be of potential utility. ${ }^{152}$

Professor Joe Sambrook of the Peter MacCallum Cancer Institute observed that "the idea of using stretches of junk DNA to track genes was wellestablished by the mid-80s." 153 Similarly, Dr Graeme Suthers, a clinical geneticist, commented, "[t]he usefulness of non-coding DNA in biomedical research has been recognised for decades." 154 Associate Professor Paul Waring has contended that Simons' invention should be limited to the use of non-coding haplotypes to determine coding region alleles in individuals without the need for information about other family members. He doubts whether the patent claims can be expanded from the HLA locus to non-coding DNA in a wide range of organisms. ${ }^{155}$

\subsection{Settlement}

Applera was initially reluctant to yield to the demands to pay licence fees in respect of non-coding DNA. It was very proud that it was leader of the private efforts to sequence the human genome. The company was unwilling to relinquish the status and kudos associated with the achievement of that big science project. Ironically, given its large patent holdings in the field of biotechnology, Applera became the white knight for universities and public research institutions. The company drew upon public research to help challenge the validity of the patents held by GTG.

In the meantime, GTG struggled to generate revenue and provide dividends to its shareholders. Indeed, the company lost AU\$14,789,624 in 2004, and AU\$11,917,008 in 2005. Since its formation as a public company, GTG has accumulated losses of $A \cup \$ 33,646,160$. The company protested that its revenues had been affected by ongoing litigation. The 2005 Annual Report stated: "It is unfortunate to note that, in recent times, the legal action against Applera Corporation has absorbed management resources that could have otherwise been spent pursuing licenses from other companies."156 To be fair, GTG is unexceptional in this respect: many biotechnology firms struggle to generate profits.

After court-ordered mediation, GTG and Applera reached a final settlement of the patent dispute in December 2005. ${ }^{157}$ The two companies

\footnotetext{
152. Little, "GTG's Inventions Concerning 'Junk' DNA," ibid.

153. Holmes, "Patently a Problem," supra note 19.

154. Ibid.

155. Paul Waring, "Patenting Genetic Information," Mutation Detection, International Symposium on Mutations in the Genome (July 2003).

156. GTG, Annual Report 2005, supra note 10 at p. 15.

157. Genetic Technologies Limited, "GTG Reports Final Settlement of its Patent Dispute with Applera Corporation" (12 December 2005), <http://www.gtg.com.au/index.asp?menuid=060.070.130\&artid=262\&fun ction $=$ NewsArticle $>$.
} 
executed a number of binding agreements, including a final settlement agreement, licence agreements, and a supply agreement. The terms of the settlement remained confidential: "The commercial terms of the settlement reached between GTG and Applera are subject to confidentiality requirements, but it can be disclosed that the settlement also includes a license to the GTG non-coding patents." 158 The District Court for Northern California formally dismissed the law suit between GTG and Applera on 30 December 2005.

After this announcement, the Australian Stock Exchange demanded additional details regarding the material terms of the agreement. In response, GTG reported that the estimated value of such agreements was AU\$15 million and the final settlement included Applera taking a licence to the GTG noncoding patents, and making payments to GTG in the form of cash, equipment, reagents, and intellectual property. ${ }^{159}$ The company stressed that the settlement would have further strategic benefits: "GTG believes that its settlement with Applera is its most strategic and therefore valuable deal to date." 160 For the most part, the marketplace appeared to be disappointed with the size of GTG's settlement with Applera. Financial pundits noted that "the market was obviously expecting something bigger. It swiped more than 20 per cent off the market value of the company." 161

Jacobson was triumphant about the settlement over the Applera litigation, suggesting that the share price of GTG should be re-valued in light of the outcome:

\begin{abstract}
Today, with the Applera matter settled, nobody in the world is challenging our patents. For a little Australian company to file a lawsuit against Applera, and have the resources to see it through, and bear the associated legal costs for three years, is obviously very significant. [...] Lots of people have hidden behind Applera, believed that time was on their side, if Applera could continue to obstruct us, and invalidate our patents-or simply wait us out.[...] Now that Applera has come to an agreement with us, they have nowhere to hide. ${ }^{162}$
\end{abstract}

Applera was disgruntled by Jacobson's characterization of the settlement. Company representative Peter Dworkin said that such statements were misleading: "The facts are that Applera has never conceded the validity or infringement of GTG's patents, and settled the case on very favourable terms for Applera in order to spare it and its customers further distraction by the litigation."163

Although the company has obtained a number of settlements and extracted a handful of commercial licences, the validity of GTG's patents has not

158. Ibid.

159. Genetic Technologies Limited, "GTG Provides Further Details of the Settlement with Applera" (15 December 2005), <http://www.gtg.com.au/index.asp?menuid=060.070.130\&artid=264\&function=NewsArticle>.

160. Genetic Technologies Limited, "GTG Reports Final Dismissal of Applera Suit, and Plans for the Future" (4 January 2006), <http://www.gtg.com.au/index.asp?menuid=060.070.130\&artid=266\&function=NewsArticle>

161. Helen Westerman \& Rebecca Urban, "Genetic wins little fight over DNA work," The Age (16 December 2005), <http://www.theage.com.au/news/business/genetic-wins-little-fight-over-dnawork/2005/12/15/1134500961973.html> [Westerman \& Urban, "Genetic wins little fight over DNA work"].

162. Graeme O'Neill, "GTG celebrates win over Applera in patent battle," Australian Biotechnology News (12 December 2005), <http://www.biotechnews.com.au/index.php?id=548699165> at p. 2.

163. Westerman \& Urban, "Genetic wins little fight over DNA work," supra note 161. 
been tested and judged in a final, conclusive fashion by a court. As such, a number of outstanding issues remain. The novelty and the inventiveness of GTG's patents remain the subject of great debate. The stance of Jacobson appears to differ from the position of the original inventor, Simons. It is unclear what weight should be attached to the expert testimony obtained by GTG from such scientists as Hood, Gresshoff, Rubenstein, and Tait. Similarly, it is not certain how a court would assess the evidence of public researchers in the field. Beyond questions of patent validity, there are larger issues about the capacity of parties to engage in such litigation. The scope of GTG's patent insurance is confidential. It is not clear whether the company can continue to wage such expensive legal battles indefinitely. Similarly, one must question whether any entity has the will and the resources to challenge the patents of GTG. The best-placed company to do so, Applera, has settled court proceedings. It remains to be seen whether there will be any other opponents to GTG.

\section{TRANS-TASMAN RIVALRY: THE AUCKLAND DISTRICT HEALTH BOARD V GENETIC TECHNOLOGIES LIMITED}

IN 2000, THE NEW ZEALAND GOVERNMENT held a Royal Commission on Genetic Modification. ${ }^{164}$ Chapter ten of the final report provided a brief overview of some of the issues arising in respect of intellectual property and biotechnology. ${ }^{165}$ The report briefly canvassed some of the ethical issues arising from patenting living organisms.

In July 2003, Cabinet directed officials of the Ministry of Health and the Ministry of Economic Development to report to Cabinet on the issues relating to the patenting of genetic material and, in particular, whether there was a need for further public consultation on these issues. ${ }^{166}$

In November 2003, the Minister for Health, Annette King, and the Associate Minister of Commerce, Judith Tizard, released a report, Implications of Granting of Patents over Genetic Material. ${ }^{167}$ The report mentioned the litigation over the patents held by Myriad in respect of BRCA1 and BRCA2. It discussed at length particular concerns about the patents held by GTG: "A number of the organisations approached by GTG expressed concern at the relatively high licence fees being charged, the excessive breadth of the patents and have questioned whether these patents in fact presented any novel information at the time of issue." 168 The report recommended that the committee "[n]ote the health and life science sectors are currently in discussion with an Australian company, Genetic Technologies Ltd, regarding their patents on non-coding DNA." 169 It

164. New Zealand, Royal Commission on Genetic Modification (2000), <http://www.mfe.govt.nz/issues/ organisms/law-changes/commission>.

165. New Zealand, Report of the Royal Commission on Genetic Modification (2002), <http://www.mfe.govt.nz/ publications/organisms/royal-commission-gm/index.html>, Chapter 10, <http://www.mfe.govt.nz/ publications/organisms/royal-commission-gm/chapter-10.pdf>.

166. Options for Addressing Genetic Material Patents, supra note 23 at p. 1

167. New Zealand-Minister of Health and Associate Minister of Commerce, Implications of the Granting of Patents Over Genetic Material (Cabinet Policy Committee, November 2003 [Implications of the Granting of Patents Over Genetic Material].

168. Ibid. at para. 18 .

169. Ibid. at p. 7. 
observed: "These patents are of concern because of their breadth and the excessively high licensing fees being asked." 170 It also stressed the need for a response: "The Ministry of Health is concerned to limit the risk from such patents being granted or exercised in the future." 171

The report noted that the Patents Act $1953^{172}$ was currently under review. A number of reforms could have an important impact upon gene patents:

The introduction of examination for obviousness will reduce the likelihood that patents will be granted over genetic material, or applications of genetic material that are no more than obvious variations on what is already known. Changes to the utility requirement will mean that patents will not be granted unless the invention is shown to have a "substantial, credible and specific" use. This makes it less likely that patents will be granted over genetic material that has no demonstrated "real world" use. ${ }^{173}$

Furthermore, the report notes:

The amended Patents Act will expand on the current exclusion from patent protection, of inventions whose commercial exploitation would be contrary to morality or "ordre public", to include "where the prevention of such exploitation is necessary to protect human, animal or plant life or health, or to avoid serious prejudice to the environment." ${ }^{174}$

Most significantly, it will be possible to revoke a granted patent on this ground. In June 2004, a second Cabinet paper was released dealing with options to address genetic patents. ${ }^{175}$ First, the New Zealand Government was reluctant to prohibit patents on genetic material per se because of the difficulties in defining types of genetic material (given the rapid advancements in the field of biotechnology), the large amount of genetic material already patented, and New Zealand's international treaty obligations. ${ }^{176}$ Second, the New Zealand Government emphasized the need to limit the breadth of claims made in biotechnology patents through the strict application of the criteria for patent validity. It noted that "the way in which the Intellectual Property Office of New Zealand (IPONZ) applies the new criteria on applications involving biological material will be crucial in determining the breadth of patents on genetic material." 177 Third, the New Zealand Government recommended a review of the Patents Act 1953 (NZ): "This review would examine how the criteria of the Act

170. Ibid. at p. 7.

171. Ibid. at p. 7.

172. Patents Act 1953 (NZ) , <http://www.legislation.govt.nz/act/public/1953/0064/latest/DLM280031.html>

173. Implications of the Granting of Patents Over Genetic Material, supra note 167 at para. 24.

174. Ibid. at para. 25 .

175. Options for Addressing Genetic Material Patents, supra note 23 at p. 1

176. Ibid. at para. 4 .

177. Ibid. at paras. 5-6. 
have been implemented and how the new criteria have been applied." 178

\subsection{Licensing}

In a letter dated May 2003, GTG proposed two alternative proposals to Dr David Sage, the Chief Medical Officer of the Auckland District Health Board (AHDB) for use of its patented inventions. In its preferred proposal, GTG mooted a publicprivate partnership with the ADHB and the Ministry of Health in New Zealand. It proposed the following:

- A sponsorship by GTG of selected NZ based genetic research projects using a substantial part ( $>50 \%$ ) of the licence fees described below for the GTG non-coding patents.

- Free access to the breast cancer susceptibility testing IP of Myriad Genetics that have been exclusively licensed to GTG for New Zealand.

- Co-operation in potential subcontracting of laboratory testing activities between the various public testing laboratories in New Zealand and GTG on a commercial basis.

- The grant of a "national licence" for unrestricted use of the GTG noncoding patents in human diagnostic testing by public sector institutions. (Administratively, this may perhaps be implemented through a master licence to one lab which would then sublicense other laboratories in the New Zealand public system.)

- An unconditional waiver from GTG for the past 13 years of infringement in New Zealand. ${ }^{179}$

GTG proposed that "[c]onsideration for such a national licence would involve a signing fee to address past infringement nationwide and an ongoing annuity for the life of the patents, which in the case of New Zealand, is until May 10, 2011." 180 It suggested that "[w]e propose the fee for signing and waiving of past infringement be NZD\$10 million and the ongoing annuity be NZD\$2 million per year." 181 The public-private partnership would consist of NZD\$5 million being offered back to New Zealand universities for research.

Alternatively, GTG proposed granting a licence to each testing laboratory individually. Such a licence would include the following:

- Unrestricted use of the GTG non-coding DNA patents in human diagnostic testing by that particular laboratory.

- Free access to the breast cancer susceptibility testing IP of Myriad Genetics that have been exclusively licensed to GTG for New Zealand.

- Co-operation in potential subcontracting of laboratory testing between the particular laboratory and GTG on a commercial basis. ${ }^{182}$

178. Ibid. at para. 7 .

179. Ian Christensen, "A Letter to David Sage, Chief Medical Officer of the Auckland District Health Board" (23 May 2003), available at Australian Broadcasting Corporation, <http://www.abc.net.au/4corners/ content/2003/20030811_patent/documents/page1.htm> at p. 1.

180. Ibid. at p. 1

181. Ibid. at p. 1

182. Ibid. at p. 1 
The company observed:

\begin{abstract}
We believe that volume related licence conditions would be impractical to administer and instead propose a simple arrangement, applicable to each laboratory, that would comprise a signing fee of NZD $\$ 2$ million and an ongoing annuity of NZD $\$ 200,000$ p.a. to May 10, 2011. ${ }^{183}$
\end{abstract}

Jonathon Holmes questioned Jacobson as to whether the New Zealand Government should pay such fees for the use of the non-coding DNA patents. The journalist noted that, under the proposed agreement, "if they don't pay for the non-coding patents, they won't get the Myriad patent either." 184 Jacobson responded that "the New Zealanders should be pleased that the test that they've been getting which is subject to a New Zealand government patent and performed by government agencies illegally will be offered lawfully." $185 \mathrm{He}$ elaborated that the quantum of the amount should not be given too much attention:

\begin{abstract}
Some of those organisations themselves don't think it's an awful lot of money but it's rather difficult to set a balanced value when you don't know how many tests are being done and you don't have all the information on which to base an intelligent assessment. Further, it's part of a bigger discussion of what we call a public/private partnership, and a substantial part of the money that was proposed to be paid for those licences to legitimise what the New Zealand government agencies are doing would in fact would be ploughed back into further research in New Zealand including New Zealand universities. ${ }^{186}$
\end{abstract}

The journalist asked whether GTG would retain intellectual property rights in research that it invested in. Jacobson observed, "That's normally the process when private or for-profit companies fund research in public institutes." $187 \mathrm{He}$ nonetheless maintained that there would be some benefit to the New Zealand taxpayer arising from the commercialization of any resulting intellectual property. ${ }^{188}$

Jonathan Holmes observed that at least a dozen Crown research institutes in New Zealand, and a number of privately funded companies, had received letters from GTG suggesting that they needed licences. He asked, "is GTG using New Zealand as some kind of test bed for Australia, in terms of licensing non-coding patents?"189 Jacobson denied any such intentions:

We see Australia and New Zealand as our home territory and we are trying to adopt a very supportive and helpful view in bringing our technology to Australia and New Zealand, and also using the power of our technology overseas to bring other technology to Australia and New Zealand. It's not that

183. Ibid. at p. 1.

184. Holmes, "Interview with Dr Mervyn Jacobson," supra note 29

185. Ibid

186. Ibid.

187. Ibid

188. Ibid.

189. Ibid. 
we wrote letters to these people, we went and saw them. There was a visit in May, I believe, where a colleague, my licensing manager and myself visited New Zealand, and we met these people to point out that, in fact, many of their activities fell within the scope of our patents and they needed licences. ${ }^{190}$

Jacobson concluded, "These are flexible ongoing negotiations, the final quantum always has to fit in or it doesn't happen or it doesn't work." ${ }^{191}$

In December 2003, Fonterra subsidiary ViaLactia Biosciences formally became GTG's first New Zealand licensee. There was some criticism about this decision from the group, Mothers Against Genetic Engineering (Madge), which is opposed to genetically modified foods. Dr Colin South, of ViaLactia, said that

the company was not using human DNA in research. He said that ViaLactia and GTG have agreed to share information on gene technology. South also said that his company has purchased the rights to animal and plant code sequences to discover traits in plants and animals. He added that information from this "junk DNA" may benefit pastoral agricultural production. ${ }^{192}$

In 2004, GTG representatives made several visits to New Zealand to talk to the Government, Crown Research Institutes, and private research laboratories about licences they say they must buy in order to legally carry out gene technology research.

The ADHB acted on behalf of all the district health boards in New Zealand. ${ }^{193}$ Jacobson said that the company revised its licence fee down to the one-off figure of NZ\$560,000. ADHB's lawyer, Bruce Northey, had corrected the original figures and provided more accurate information about the level of use of the genetic tests by the 20 health boards, which was much lower than originally estimated. He observed that: "The time it would take to settle the matter depended on 'how much he (Jacobson) wants to arm wrestle'."194

Genesis Research Corporation, an Auckland-based listed biotech company,

is one New Zealand organisation that has made a stand against GTG. Chief executive $\mathrm{Dr}$ Jim Watson has spoken out previously about GTG's assurances that it would enter litigation to enforce licences, as it was protected by its patent insurance. He also feared some [New Zealand] businesses might [pay] for a licence to protect themselves, even if they were uncertain whether they were infringing GTG patents. ${ }^{195}$

After consulting lawyers, Watson was confident that his company did not infringe GTG patents. In response, Jacobson argued that Watson's arguments

192. "ViaLactia Scuttles Madge Mischief," Food Industry Week (10 October 2003).

193. Paul Gorman, "Board Negotiates With Research Team: Kiwi Funds Money In Junk," Christchurch Press (16 February 2004). 
were "wishful thinking." 196

In June 2004, GTG granted a research licence and a commercial licence for the non-coding patents to Ovita Limited of Dunedin, New Zealand. ${ }^{197}$ AgGenomics had signed a contract with Ovita to provide genetic-testing services on DNA samples of sheep from Australia and New Zealand at the AgGenomics high-throughput DNA laboratory at La Trobe University in Melbourne. Ovita will now pay to GTG an up-front signing fee and royalties on their future commercial sales. The Melbourne company observed, "GTG similarly stands ready to offer its assistance and technology to other New Zealand organisations, to support the efficiency and quality of New Zealand's agricultural output." 198

\subsection{Litigation}

In June 2004 Jacobson expressed his doubts whether negotiations with the ADHB lawyer Bruce Northey, representing all the district health boards, were "proceeding in good faith." 199 He observed with exasperation:

I can't deal with anyone who is that obstructive and obfuscatory. I have stepped out of the proceedings and handed it over to our attorneys. He keeps changing his position in a way that it is impossible to deal with him. ${ }^{200}$

He did not make it clear whether GTG was considering legal action against the health boards. "Jacobson said he wanted to ask Northey why, as a New Zealand Government representative, he spent his day encouraging people not to deal with GTG and to disregard GTG's patents which had been adopted by the Government." 201

Northey said he was not upset by Jacobson's comments about "not proceeding in good faith" and did not take the comments personally. He observed the following:

He's certainly put that to me. Good faith requires openness and transparency. We have disclosed fully to him what tests we are doing and what issues we have.

[...]

When someone comes to us for $\$ 30$ million, you don't just go down the street and ask someone what to do. Business communications from day one have included lawyers. I'm not averse to that. We might get a more rational response than we do from him. It's not legal action he's talking about. ${ }^{202}$

Northey said: "We've been working with him (Jacobson) for a while, asked him a number of questions, done a great deal of due diligence, (but) certainly not

196. Ibid.

197. Genetic Technologies Limited, "GTG Grants second license in New Zealand: GTG Grants License to Ovita" (28 June 2004), <http://www.gtg.com.au/index.asp?menuid=060.070.130.010\&artid=152>

198. Ibid.

199. Paul Gorman, "Trans-Tasman DNA Row Spirals," Christchurch Press (30 June 2004) at p. 1.

200. Ibid. at p. 1.

201. Ibid. at p. 1

202. Ibid. at p. 1. 
doing anything inconsistent with the laws of New Zealand." 203

In August 2004, ADHB announced that it was taking pre-emptive legal action against GTG in the High Court in New Zealand. ${ }^{204}$ Northey said ADHB decided to challenge GTG following an extensive analysis of the scientific and legal basis of GTG's patents, involving members and advisers to the $\mathrm{New}$ Zealand health services community. ADHB is satisfied that its DNA testing does not infringe the patents and doubts that the patent claims are valid. ADHB has accused GTG of using implied threats of legal action to force the ADHB to pay access and royalty fees for the GTG patents. GTG failed to answer specific questions about the application of its patents to ADHB's tests despite repeated requests for it to do so. Northey noted, "Nowhere else in the world is a public health provider paying licence fees to GTG for tests that are standard globally." 205 He observed, "It is curious that GTG has chosen to make such demands in New Zealand for the first time." 206 Northey said the ADHB's position was that, while New Zealand encourages and supports research and development and the commercial protection of these through patents, patent licence demands needed to be subjected to proper scrutiny before public money was spent.

Northey confirmed that GTG's co-founder and inventor of the company's non-coding DNA gene-testing techniques, Dr Malcolm Simons, had been advising the $A D H B$ and its legal counsel during its analysis. "It had yielded a 'consensus understanding' of the claims and their relevance to all the genetic tests used by the ADHB that could be subject to licence fees if GTG's interpretation of its patent rights was upheld." 207 Northey said, "Malcolm's summary was that, while the patents can be interpreted to relate to what he invented, nobody employing the methodology would be infringing the patents." 208 Northey said that the ADHB was prepared for the court case to happen as quickly as possible. The ADHB issued proceedings in the High Court in Auckland alleging "groundless threats of infringement" by GTG. 209

In response, Jacobson was critical of ADHB's account (in the media release) of negotiations with GTG over the past 18 months. He questioned why the New Zealand Government would issue a patent and then challenge the validity of such an invention:

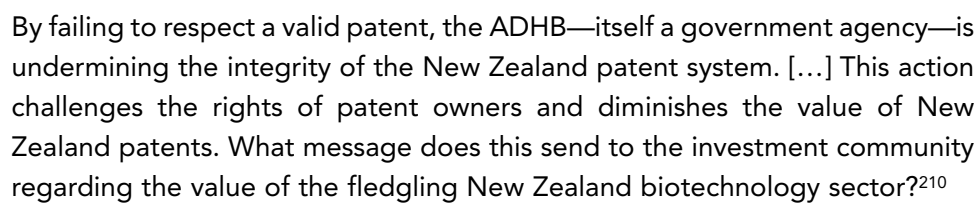

Such comments, of course, overlook the obvious point-the New Zealand Intellectual Property Office operates independently from the Government. The

204. "Legal Action Against GTG," Christchurch Press (19 August 2004).

205. Graham O'Neil, "NZ health service takes on GTG over licence fees," Australian Biotechnology News (24 August 2004), <http://www.biotechnews.com.au/index.php/id;813052581>.

206. Ibid.

207. Ibid.

208. Ibid

209. Paul Gorman, "NZ Health Boards In Patent Dispute," Christchurch Press (21 August 2004) at p. 3.

210. Genetic Technologies Limited, "GTG Supports Patent Protection" (19 August 2004), <http://www.gtg.com. au/index.asp? menuid=060.070.200.020.010\&artid=205>. 
Health Boards are perfectly entitled to take legal action to challenge the validity of granted patents.

\title{
4.3. Settlement
}

In June 2005, the New Zealand High Court appointed a retired judge, Justice Barry Pattinson, to oversee mediation between GTG and ADHB. ${ }^{211}$ In July 2005, the parties reached a settlement:

\begin{abstract}
As a consequence of this settlement, the current High Court proceedings between the parties will now be withdrawn, without payment by either party to the other. In addition, both parties have agreed not to pursue the other in future, in relation to these patents. In addition, as part of the same settlement, GTG is now granting commercial licences to the non-coding patents to four commercial New Zealand entities-AgResearch, HortResearch, Forest Research and Livestock Improvement Corporation-who will together pay NZD\$450,000 to GTG. ${ }^{212}$
\end{abstract}

The parties agreed to keep the precise terms of the settlement confidential, while allowing each to comment on its circumstances.

The New Zealand Herald reported the result as a victory for the ADHB: "In the first case of its kind against Government-funded organisations, GTG has been sent packing empty-handed after mediation which saw High Court proceedings withdrawn without costs and both parties agreeing not to pursue each other again in future over the patents." ${ }^{213}$ Likewise, the Independent Business Weekly also suggested, "New Zealand's publicly funded health boards continue to defy the licence-holder of a breast-cancer gene test they use, despite settling a two-year legal dispute last week." 214 ADHB lawyer Bruce Northey said that the mediation process was "interesting." He was satisfied with the outcome and with the fact that the District Health Boards would not have to pay GTG fees. "You come along to a country and demand considerable sums of money and you walk away with nothing." 215 GTG's decision not to claim royalties "vindicated" the ADHB's decision to challenge the validity of GTG's patent claims. He said that GTG had declined to produce evidence for "robust scientific and commercial scrutiny" of the patents and their relationship to the health boards' activities. ${ }^{216}$

GTG executive chairman Mervyn Jacobson was philosophical about the settlement, seeking to downplay its significance, suggesting that New Zealand was a special case:

The overall message is that drawn-out disputes are not good for either side.

We needed to reach a settlement and get on with life. For whatever reason,

211. Paul Gorman, "Mediation Causes Row," Christchurch Press (26 March 2005) at p. 8.

212. Genetic Technologies Limited, "Mediation in New Zealand Results in Final Settlement of Legal Action" (7 July 2005), <http://www.gtg.com.au/index.asp?menuid=060.070.130\&artid=244\&function=NewsArticle $>$.

213. "GTG's Bid for Health Board Patent Fees Fails," New Zealand Herald (8 July 2005) ["GTG's Bid"].

214. Denise McNabb, "Health Boards Defy Gene Test Claims," The Independent Business Weekly (13 July 2005).

215. "GTG's Bid," supra note 213.

216. Ibid. 
they initially chose to negotiate, and then fight, but finally, we've reached a settlement that is very acceptable to both parties. From GTG's perspective, it addresses one small group, in one small country. We can now get back to the big picture, including our Nasdaq listing and our global licensing strategy. ${ }^{217}$

Jacobson said that he was also happy with the outcome or the company would not have settled. GTG was receiving royalties from other patents in New Zealand and the decision would have no impact on those or on future business opportunities. However, he said Northey was being "a little self-serving talking about vindication." 218 Jacobson concluded that, at the very best, the ADHB had only gained a pyrrhic victory: "The reality is they spent between $\$ 700,000$ and $\$ 1 \mathrm{~m}$ to prove a point which they could have achieved from working with us for half that amount." 219

\section{GENE PATENTING AND HUMAN HEALTH: THE AUSTRALIAN LAW REFORM COMMISSION INQUIRY}

IN DECEMBER 2002, THE FEDERAL ATTORNEY GENERAL, The Honourable Daryl Williams, commissioned the Australian Law Reform Commission (ALRC) to undertake a review of intellectual property rights over genes and genetic and related technologies, with a particular focus on human health issues. ${ }^{220}$ This inquiry was prompted in particular by concerns about patents held on genetic testing by biotechnology companies such as Myriad Genetics and GTG. The ALRC commented upon the impetus for the review in the executive summary of its final report:

$[\mathrm{H}]$ ealth officials in Australia and overseas were expressing growing concern about the implications of gene patents and licences for the cost of and access to healthcare. Of special concern was the behaviour of one United States company-Myriad Genetics Inc (Myriad)—which holds patents over methods and materials used to isolate and detect mutations in two genes that may indicate a predisposition to breast and ovarian cancer (BRCA1 and BRCA2). $[\ldots]$

In Australia, Myriad licensed its BRCA1 patents to an Australian company, Genetic Technologies Limited (GTG). GTG announced during the course of the ALRC's Inquiry that it was not proposing to charge a licence fee for BRCA1 testing by public sector laboratories, nor would it require that all BRCA1 testing in Australia be conducted at its laboratories. Nevertheless, concerns

217. Graeme O’Neill, "GTG Boss Reflects on 'Unusual' License Dispute," Australian Biotechnology News (8 July 2005), <http://www.biotechnews.com.au/index.php?id=1192139376>.

218. "GTG's Bid," supra note 213.

219. Ibid.

220. "Inquiry into Human Genetic Property Issues," Press Release (17 December 2002). 
remained within the health sector that other companies holding patents over genes associated with predictive and diagnostic testing would, in time, replicate the behaviour of Myriad. ${ }^{221}$

In this context, the ALRC considered the impact of gene patents upon research (and its subsequent application and commercialization), the Australian biotechnology sector, and the cost-effective provision of health care in Australia. There was much political debate over the impact of gene patents upon research, health care, and competition.

Along with biotechnology and pharmaceutical companies, GTG argued that the current regime of patent law should not be changed, lest investment in the marketplace be affected. Jacobson stated the following:

\begin{abstract}
I see the patent process as a very wholesome process. It's been around for 400 years. It started in Britain, but most countries in the world have adopted it, modified it. It works very well. You interfere with that process, you interfere with invention, you interfere with innovation, with risk taking. And, in fact, in Australia, if you drastically interfere with an established process, you run the risk of damaging or destroying biotechnology in Australia, which not only harms biotechnology companies but it's negative for Australian health care. ${ }^{222}$
\end{abstract}

GTG argued that isolated genetic materials and genetic products should be regarded as "inventions" rather than "discoveries," for the purposes of Australian patent law. It argued against prohibitions in respect of the patenting of genes, methods of human treatment, or medical diagnostics. GTG was hostile to the idea that ethical and social concerns about patents on genetic materials and technologies should be addressed through the patent system. It denied that there was any need to make special provision for individuals or groups whose genetic samples are used to make a patented invention, to benefit from any profits from the patent. GTG argued that changes to the requirements for patentability under Australian law for inventions involving genetic materials and technologies would hinder Australia's quest to be at the cutting edge of global research and conflict with Australia's obligations under the TRIPS Agreement. ${ }^{223}$

By contrast, health care providers, scientific groups, and academics argued that there was a need to reform the patent system in order to accommodate genetic technologies. ${ }^{224}$ Some considered solutions that regulated

221. "Genes and Ingenuity," supra note 24, Executive Summary.

222. Holmes, "Patently a Problem," supra note 19

223. Agreement Establishing the World Trade Organization, Annex 1C: Agreement on Trade-Related Aspects of Intellectual Property Rights, 15 April 1994, 1869 U.N.T.S. 299,

<http://www.wto.org/english/docs_e/legal_e/27-trips_01_e.htm>, 33 I.L.M. 81 [TRIPS Agreement].

Article 27.1 of the TRIPS Agreement provides, "patents shall be available and patent rights enjoyable without discrimination as to the [...] field of technology." This is subject to article 27.3 which allows Members to exclude from patentability, "diagnostic, therapeutic and surgical methods for the treatment of humans or animals" and "plants and animals other than micro-organisms, and essentially biological processes for the production of plants or animals other than non-biological and microbiological processes." Article 30 further provides, "Members may provide limited exceptions to the exclusive rights conferred by a patent, provided that such exceptions do not unreasonably conflict with a normal exploitation of the patent and do not unreasonably prejudice the legitimate interests of the patent owner, taking account of the legitimate interests of third parties."

224. "Genes and Ingenuity," supra note 24 at pp. 115-116. 
the grant of patents, such as refining the standards of novelty, inventive step, and utility. Others considered whether there should be new defences to claims of infringement of gene patents, such as where patents are used for research, for private non-commercial purposes, or for medical treatment. Some supported solutions that regulated the exploitation and abuse of patents. They investigated the circumstances in which Crown use, ${ }^{225}$ compulsory acquisition, ${ }^{226}$ and the compulsory licensing provisions ${ }^{227}$ of the Patents Act 1990 could be used.

Finally, a number of idealists expressed per se objections to the patenting of genes and gene sequences. For instance, Graeme Suthers of the South Australian Clinical Genetics Service argued that biological inventions should not be allowed to be patentable subject matter:

\begin{abstract}
Genetic research is increasingly being used for private profit. Many patents have been granted for items that should not be patentable and that this has the potential to greatly increase the cost of vital medicines and tests. The law should be changed so that human genetic information cannot be placed under private control. ${ }^{228}$
\end{abstract}

Such complaints were grounded in ethical concerns about the commercialization of scientific discoveries.

\title{
5.1. Political Debate
}

The debate over the effects of gene patents upon health care was a highly political matter in Australia. The Royal College of Pathologists of Australasia and six other similar entities sent a letter to the Attorneys General and the Ministers of Health of all the States and the Commonwealth, warning that a critical service was at risk:

\footnotetext{
The demand for genetic testing is continuing to grow, and high costs will delay or curtail the application of these tests in many areas of healthcare. Experience in both the US and Canada is that enforcement of gene patents that impact on medical diagnosis resulted in increased costs, a marked reduction in genetic testing, medical and social consequences for those patients denied testing, and increased costs necessitated by using less efficient or less accurate tests. ${ }^{229}$
}

The Royal College said, "Genetic Technologies is now seeking to enforce the patents on both breast cancer genes and non-coding DNA. Enforcement of these patents will have far-reaching effects and could affect all genetic testing in the future." 230

225. Patents Act 1990, supra note 64, s. 163

226. Ibid., s. 171 .

227. Ibid., s. 133

228. Graeme Suthers, "Our Genes: Humanity's Heritage or Cash Cow?" (2004) 67 Issues 23 [Suthers, "Our Genes"].

229. Melissa Trudinger, "Gene Patents: Pathologists call on Governments to Challenge GTG," Australian Biotechnology News (12 May 2003), <http://www.biotechnews.com.au/index.php?id=1851794925>.

230. Holmes, "Patently a Problem," supra note 19. 
Within two days, the Royal College received a letter from GTG's lawyer, Clayton Utz, demanding a retraction. ${ }^{231}$ Jacobson denied that the company had ever threatened to enforce its patents in Australia:

Well, I'm puzzled that the College of Pathologists takes an extreme view without ever consulting us to establish the facts, and makes certain statements which turned out to be wrong. And that seemed to be their priority-to criticise us in some way - rather than to be more concerned about what we're concerned about, which is the level of care of the women of Australia. 232

Undoubtedly, the Royal College of Pathologists were given the impression that GTG would enforce its patents in light of its public statements about "genetic piracy" after the cross-licensing deal with Myriad. The College, though, conceded that it could provide no evidence that GTG intended to enforce such patents in Australia and New Zealand. Accordingly, the Royal College of Pathologists agreed to retract the statement. ${ }^{233}$

GTG denied that its patents on non-coding DNA and genomic mapping would stifle research. Jacobson stated the following:

\begin{abstract}
GTG is itself a research group, and continues to support basic research in collaboration with leading Australian universities and institutes-in such areas as cancer susceptibility, foetal cell separation and testing, AIDS research, treatment of pathogenic infections etc. In fact, our non-coding patents were issued to us specifically as a result of our own past research and success in this area. GTG actively encourages research, and for anyone to suggest otherwise, is mischievous. ${ }^{234}$
\end{abstract}

GTG argued that the current public health system was inefficient in its delivery of genetic testing because of duplication of services, organisational fragmentation, and the lack of research infrastructure. The company contended that the private sector could provide a comprehensive system of genetic testing, which could improve upon the quality and availability of the current service.

\title{
5.2. Final Report
}

The ALRC released an issue paper in July $2003,{ }^{235}$ a discussion paper in January 2004, ${ }^{236}$ and a final report in June 2004, which was tabled in Parliament in August

233. Genetic Technologies Limited, "A Report to Shareholders Genetic Technologies Limited Obtains Retraction of Wrong Statements by the Royal College of Pathologists of Australasia" (9 July 2003), <http://www.gtg. com.au/index.asp?menuid=060.070.130.010\&artid=98>; Melissa Trudinger, "Pathologists Back Down from GTG Attack," Australian Biotechnology News (11 July 2003), <http://www.biotechnews.com.au/index. php?id=265599407>

234. Mervyn Jacobson, "Bringing the Latest Advances in Cancer Susceptibility Testing to Australia," Australian Stock Exchange Company Announcement (9 December 2002), <http://www.asx.com.au/asxpdf/20021209/ pdf/00335135.pdf > at p. 2.

235. "Gene Patenting and Human Health," Issue Paper, supra note 24.

236. "Gene Patenting and Human Health," Discussion Paper, supra note 24 
2004. ${ }^{237}$ The leviathan 678-page final report contains fifty recommendations. The ALRC took a decidedly cautious, tentative approach in its final report:

\begin{abstract}
In view of the equivocal nature of evidence about adverse impacts on research and healthcare, the ALRC considers that it should adopt a cautious approach towards recommending radical changes in patent law and practice. Major changes should be proposed only in response to demonstrated problems. This is particularly so given that such changes have uncertain flow-on effects; for example, on future investment and innovation in genetic technologies, and on the development of the biotechnology industry. On the other hand, caution does not imply inaction, and the patent system must be flexible enough to deal with problems as they emerge..$^{238}$
\end{abstract}

The ALRC offered various recommendations for reform to government, independent agencies, industry, and funding agencies. It noted, "in a more complex environment in which authority is more diffused, modern law reform efforts usually involve a mix of strategies, including legislation, guidelines, principles, education programs, and changed practices." 239 As a result, only a few policy recommendations required legislative action.

First, the ALRC recommended that the Australian Government reform the Patents Act 1990 to provide that an invention will satisfy the requirement of usefulness in section 18(1)(c) of the Patents Act 1990 "only if the patent application discloses a specific, substantial, and credible use." 240 The law reform body observed the following:

The ALRC considers that reform is needed to the way in which the usefulness of an invention is addressed in the requirements for patentability. It was evident from submissions and consultations early in the Inquiry that there is considerable confusion about the application of the usefulness requirement. These misunderstandings relate to the extent to which an invention claimed in a patent application must be useful; how such a requirement is imposed; the standard for satisfying this requirement; and the extent to which usefulness can or should limit the scope of patent claims. ${ }^{241}$

Article 17.9.12 of the Australia-United States Free Trade Agreement $2004^{242}$ states: "Each Party shall provide that a claimed invention is useful if it has a specific, substantial, and credible utility." 243 As a result of this Article, the Australian Government will be obliged to adopt USPTO utility standards. Recently, in Re Fisher, the US Court of Appeals for the Federal Circuit held that Monsanto could not patent express sequence tags in respect of maize because

237. "Genes and Ingenuity," supra note 24.

238. Ibid. at para. 3.74.

239. Ibid. at para. 1.21

240. Ibid. at para. 1.21.

241. Ibid. at para. 6.138.

242. Australia-United States Free Trade Agreement (1 May 2004), 2005 A.T.S. 1, <http://www.dfat.gov.au/trade/ negotiations/us_fta/final-text/index.html> [AU-USA FTA]

243. Ibid., ch. 17, art. 17.9, 13. 
there was a lack of utility and a lack of disclosure. ${ }^{244}$ No doubt this will also be a persuasive authority in Australia.

Second, the ALRC proposed that the Australian Government should recognize a defence under patent law for experimental use:

The ALRC believes it is desirable to remove uncertainty about the existence and scope of an experimental use exemption in Australian law. This approach received broad support in submissions. The existing uncertainty is unhelpful to the research community and commercial organisations. It has the potential to result in under-investment in basic research; and to hinder innovation if researchers become concerned that their activities may lead to legal action by patent holders. ${ }^{245}$

The ALRC rejected the narrow view of the research exemption adopted by the US Court of Appeals for the Federal Circuit in Madey, which affirmed that the defence was limited to actions performed "for amusement, to satisfy idle curiosity, or for strictly philosophical inquiry."246 It instead supported the approach in the European Union, in which the defence of experimental use extended to research on a patented invention, but not with an invention. The ALRC concluded: "Moreover, basing a new provision on the European Union model would promote harmonization of Australian patent law with the law of a major trading bloc, and would give Australian courts the benefit of considering European case law in applying the new provisions." 247

Third, the ALRC proposed a number of amendments to the existing compulsory licensing regime in chapter 12 of the Patents Act 1990, "Given the unique nature of many biotechnology inventions, and hence their possible lack of substitutability, the anti-competitive exploitation of a patent could have significant implications for downstream research or access to certain healthcare services." 248 The ALRC recommended that the federal government should amend the Patents Act 1990 to insert a competition-based test as an additional ground for the grant of a compulsory licence. It believed that such a test would address those circumstances in which there is a public interest in enhanced competition in a market, and the patent holder has not met reasonable requirements for access to the patented invention. The provision of compulsory licensing would be useful in the future, if a company abuses its dominant market position. Such measures would also be relevant in circumstances where the patent holder blocked access to inventions for research, treatments, and diagnosis.

Fourth, the ALRC promoted the use or acquisition of patented technologies pursuant to the Crown use provisions in chapter 17 of the Patents Act $1990 .{ }^{249}$ The report observed the following:

244. Re Fisher, 421 F.3d 1365 (Fed Circ 2005), <http://www.fedcir.gov/opinions/04-1465.pdf>.

245. "Genes and Ingenuity," supra note 24 at para. 13.77; for a summary of the wider debate over patent law and experimental use, see Rimmer, "Freedom to Tinker," supra note 57.

246. Madey, supra note 57 at para. 63.

247. "Genes and Ingenuity," supra note 24 at para. 13.92

248. Ibid. at para. 27.38.

249. Ibid. at paras. 26.1-26.68 
In some circumstances, the exercise of patent rights may have adverse implications for governmental or public interests. Where this is the case, the Crown use provisions ensure that governments can step in to exploit a patent or authorise others to do so. These provisions may be seen as a "safety valve" in particular cases, preventing the public interest from being subverted by the patent system. ${ }^{250}$

The ALRC advised that the Commonwealth should amend the Patents Act to clarify that, for the purposes of the Crown use provisions, an invention is exploited "for the services of the Commonwealth or the State" if the exploitation of the invention is for the provision of health care services or products to members of the public. Furthermore, it suggested that the Commonwealth should amend the Patents Act to provide that, when a patent is exploited or acquired under the Crown use or Crown acquisition provisions in chapter 17 of the Patents Act, the Crown must pay remuneration or compensation. ${ }^{251}$

Finally, the ALRC considered the relationship between intellectual property law and competition law in the context of biotechnology. ${ }^{252}$ The ALRC recommended that the Commonwealth should amend section 51(3) of the Trade Practices Act 1974 (Cth) (TPA) to clarify the relationship between Part IV of the TPA and intellectual property rights. The ALRC also advised that the Australian Competition and Consumer Commission (ACCC) should develop guidelines to clarify the relationship between Part IV of the TPA and intellectual property rights. The ALRC envisaged that such guidelines should extend to the exploitation of intellectual property rights in genetic materials and technologies, including patent pools and cross-licensing. As the need arises, the ACCC should review the conduct of firms dealing with genetic materials and technologies protected by intellectual property rights to determine whether their conduct is anticompetitive within the meaning of Part IV of the TPA. The ALRC also recommended that Commonwealth, State, and Territory health departments, and other stakeholders should make use of existing complaint procedures under the TPA where evidence arises of conduct that may have an adverse impact on medical research or the cost-effective provision of health care.

Arguably, this reform agenda is a modest one. The solutions proffered by the ALRC are targeted mainly at the exploitation of gene patents. The fundamental weakness of the final report was its failure to address the initial grant of gene patents by the Patent Office. The ALRC failed to address patent criteria dealing with the threshold of inventiveness, such as "novelty" and "inventive step." As a result, there remains a danger of the Patent Office granting broad patents of dubious inventiveness under the Patents Act. Arguably, the ALRC should have sought to amend the Patents Act to raise the standards of "novelty" and "inventive step" in section 18(1)(b). In his dissenting judgment in Aktiebolaget Hässle v. Alphapharm, Justice Kirby observed that patents should only be granted if there is sufficient ingenuity: "It is not diligence and determination or the input of time, labour, skill and effort or the expenditure of 
resources that meet the criteria in the Act." 253 His Honour argued that there was a need for the test of "novelty" and "inventive step" of the Patents Act to reflect the complexities of contemporary science:

\begin{abstract}
But the Act talks to science and invention at different stages. Its origins lie in earlier centuries and nowadays science, in the field of nuclear physics and the field of biology and in the field of informatics, has gone beyond the scope, immediate Eureka-type exclamations, it is more complex, and therefore, if the Act is to speak with relevance to science and technology as they exist today, the ultimate question that has to be addressed is whether in that moving context what is obvious moves with that change and therefore that with the advance of the availability of information, including through the Internet and so on, that you face up to the reality of that factual substratum to which the statute speaks. ${ }^{254}$
\end{abstract}

The ALRC should have also directed judges to attribute greater creativity and problem-solving skills to a person "skilled in the art." McGill University academics Richard Gold and Karen Durrell have argued that "the skilled reader permits the courts to introduce flexibility into patent law so that the context in which inventions are made and used is considered."255 These Canadian authors suggested that this device is particularly useful in dealing with biotechnological inventions:

The use of the skilled reader permits the adaptation of patent law in a flexible yet transparent manner that at once ensures the continued relevance and functioning of patent law with the ability to adapt the law to take into account the particularities of new technologies such as biotechnology and information technology. 256

Perhaps the GTG patents on non-coding DNA and genomic mapping would have never been granted if such rigorous standards had been in place.

Furthermore, the ALRC was remiss in its failure to canvass a wider range of patent infringement and exceptions to patent infringement. The introduction of a defence of experimental use alone is insufficient. Given the expansion of the scope of patentable subject matter, there is a need in turn to broaden the range of exceptions to patent infringement. The ALRC should have sought to take advantage of the flexibilities available for patent exceptions under the TRIPS Agreement. In addition, there should be a defence in respect of personal, noncommercial use of patented inventions. The federal government should also introduce a limited liability for medical practitioners in respect of patent infringement. This position is a necessary response given that methods of human

253. Aktiebolaget Hässle v. Alphapharm Pty Limited, 2002 HCA 59, <http://www.austlii.edu.au/au/cases/cth/ HCA/2002/59.html>, (2002), 212 C.L.R. 411 at para. 161.

254. Kirby J., Aktiebolaget Hässle v. Alphapharm Pty, transcripts, <http://www.austlii.edu.au/cgi-bin/disp.pl/au/ other/hca/transcripts/2001/S287/1.html>.

255. Richard Gold \& Karen Durrell, "Innovating the Skilled Reader: Tailoring Patent Law to New Technologies," (2005) 19:1 Intellectual Property Journal 189, <http://www.ipgen.umontreal.ca/CIPP/040415_wp_en.pdf> at p. 192.

256. Ibid. at pp. 224-225. 
treatment have been treated as patentable subject matter. ${ }^{257}$ The report was also somewhat hollow because it was reluctant to engage with the ethical concerns held by many of the public in respect of gene patents. It is recommended that the Patents Act be amended to provide the requirement that a patent can only be granted if there is evidence of informed consent and benefit sharing. ${ }^{258}$ This requirement is a general one. It could arise in the context of genetic testing and biomedical research.

\title{
5.3. Government Responses
}

Some commercial entities sought to portray the report as showing no empirical evidence of impacts on research and health care. GTG Director, Deon Venter, argued, "The report points out that many of the fears expressed about the much-touted negative impacts on research and healthcare were groundless." 259 In response, GTG made the following controversial comments about the verdict of the final report delivered by the ALRC:

\begin{abstract}
Finally, we are pleased to note the Australian Law Reform Commission (ALRC) this week presented its 700-page report, entitled "Genes \& Ingenuity: Gene Patents and Human Health (ALRC 99)" to Federal Parliament. GTG wishes to reaffirm it fully supports the work of ALRC. Indeed, GTG was pleased to be invited twice, and to have appeared twice, before ALRC, to offer its expertise and views to ALRC. In summary, ALRC has confirmed to GTG that it saw no problem with GTG's patents or licensing practices, and GTG is pleased with the findings of ALRC. 260
\end{abstract}

Such a gloss on the final report is inaccurate. The ALRC has given no such public or private undertakings that it had no problem with GTG's patents or licensing practices. Indeed, the law reform body studiously avoided dwelling upon any particular controversy in the belief that such an approach would be unrepresentative. Instead, the ALRC offered general recommendations on reforms to patent law and genetic technologies. It is not the role of the law reform body to rule one way or the other upon the legitimacy of GTG's inventions. The validity of the patents and the legitimacy of the licensing practices is ultimately a matter for the Patent Office and the courts.

257. Anaesthetic Supplies Pty Ltd v. Rescare Ltd (1994), 28 I.P.R. 383, <http://www.austlii.edu.au/au/cases/cth/ federal_ct/unrep6846.html>; Bristol-Myers Squibb Company v. FH Faulding \& Co Limited (2000), 46 I.P.R. 553 , <http://www.austlii.edu.au/au/cases/cth/federal_ct/2000/316.html >; for the United States, see Pallin v. Singer (D Vt 1995), 36 U.S.P.Q. (2d) 1050; Metabolite Laboratories Inc. v. Laboratory Corporation of America Holdings (LabCorp), 370 F.3d 1354 (Fed Cir 2004), <http://www.ll.georgetown.edu/federal/judicial/fed/ opinions/03opinions/03-1120.html>; for Canada, see Apotex Inc. v. Wellcome Foundation Ltd., 2002 SCC 77, <http://csc.lexum.umontreal.ca/en/2002/2002scc77/2002scc77.html>, [2002] 4 S.C.R. 153; for New Zealand, see Pfizer v. Commissioner of Patents, [2005] 1 N.Z.L.R. 364.

258. See Greenberg v. Miami Children's Hospital Research Institute, 264 F.Supp. 2d 1064 (SD Fla 2003); Donna Gitter, "Ownership of Human Tissue: A Proposal for Federal Recognition of Human Research Participants' Property Rights in Their Biological Material," (2004) 61:1 Washington and Lee Law Review 257; Matthew Rimmer, "Miami Heat: Patent Law, Informed Consent, and Benefit-Sharing," (2006) 3 Journal of International Biotechnology Law 177.

259. Melissa Trudinger, "Gene Patent System Ain't Broke, But Needs Fine Tuning: ALRC," Australian Biotechnology News (6 September 2004), <http://www.biotechnews.com.au/index.php?id=1801276438>

260. Genetic Technologies Limited, "GTG Reports on the Current Status of Legal Action to Protect its Patents" (3 September 2004), <http://www.gtg.com.au/index.asp?menuid=060.070.130.010\&artid=158>. 
It is fair to say that the ALRC did not favour the opponents of gene patents. The law reform body was unwilling to tamper with the broad, openended definition of "manner of manufacture." Graeme Suthers argued that patents should not be granted in respect of genes and gene sequences on the grounds that they were mere scientific discoveries. ${ }^{261}$ By contrast, GTG argued that isolated genetic materials and genetic products should be regarded as "inventions," rather than "discoveries," for the purposes of Australian patent law. The company argued against prohibitions in respect of the patenting of genes and gene sequences. In the end, the ALRC held that there should be no absolute prohibitions upon the patenting of genes and gene sequences.

Ultimately, the ALRC did not accept the submissions of GTG that there should be no reforms to the Australian patent system, and that the status quo should be preserved. The Commission made a number of modest recommendations for reform of the Patents Act. The ALRC recommended the establishment of a defence of experimental use, despite the protests of GTG that there was no need for such an exemption. The ALRC also called for reforms to compulsory licensing and Crown use, to enable such mechanisms to be more accessible. By contrast, GTG was hostile to government intervention in relation to patents that had been granted by the Patent Office. In its view, the marketplace should resolve issues concerning access to patented inventions.

The federal government showed some initial reluctance in tabling the final report of the ALRC on gene patents and human health. In August 2004, there was a debate raging over whether the proposed Australia-United States Free Trade Agreement 2004 would result in the evergreening of pharmaceutical drug patents. ${ }^{262}$ The Liberal Federal Government argued that the patent system was working well, and there was no need to introduce reforms to the implementing legislation. By contrast, the Opposition maintained that there was a need for amendments to discourage the evergreening of pharmaceutical drug patents. In the end, the major parties agreed to pass the Australia-United States Free Trade Agreement 2004 subject to the amendments proposed by the Opposition. Once this controversy subsided, the federal government released the final report of the ALRC on gene patents and human health in September 2004. There was little political comment upon the findings of the final report, which was unsurprising given that the federal election took place in October 2004.

Since its re-election, the Liberal federal government has yet to respond to the recommendations of the law reform body either in respect of gene patenting and human health, or the protection of human genetic information. There remain doubts as to whether the topic will be a legislative priority. Particular issues have been hived off for further consideration by other law

261. Suthers, "Our Genes," supra note 228.

262. For a discussion of the debate over patent law and evergreening, see Kate Burton \& Jacob Varghese, "The PBS and the Australia-US Free Trade Agreement," Parliament of Australia Research Note no. 32004-2005 (22 July 2004), <http://www.aph.gov.au/library/pubs/rn/2004-05/05rn03.htm>; Charles Lawson \& Catherine Pickering, "'TRIPs-Plus' Patent Privileges_An Intellectual Property 'Cargo Cult' in Australia," (2004) 22:4 Prometheus 355; Peter Drahos et al., "Pharmaceuticals, Intellectual Property and Free Trade: The Case of the US-Australia Free Trade Agreement," (2004) 22:3 Prometheus 243, <http://cgkd.anu.edu.au/menus/ PDFs/drahos\%20et\%20al\%20prometheus\%20FTA.pdf>; Peter Sainsbury, "Australia-United States Free Trade Agreement and the Australian Pharmaceutical Benefits Scheme," (2004) 4:2 Yale Journal of Health Policy, Law and Ethics 387; Matthew Rimmer, "The Jean Chrétien Pledge to Africa Act: Patent Law and Humanitarian Aid," (2005) 15:7 Expert Opinion on Therapeutic Patents 889. 
reform bodies. ACIP has undertaken inquiries into both the defence of experimental and Crown use. The government has yet to table its response to such investigations. The federal government will also be sensitive to the impact of any such reforms upon key industries, particularly the pharmaceutical and biotechnology sectors. It would be loath to introduce any amendments to the Patents Act, which could jeopardize investment in research and development. Countervailing that concern, the federal government is alarmed by the rising costs associated with the Pharmaceutical Benefits Scheme. It may be willing to take some legislative action to curtail some of the expenses associated with the emergence of new medical diagnostics, such as genetic tests.

\section{CONCLUSION}

THIS ARTICLE HAS CONSIDERED THE PUBLIC DEBATE over the patents held by GTG in respect of non-coding DNA, haplotyping, and genomic mapping. It has suggested that such patents are deserving of particular attention, both because of the exceptional breadth of their claims, and their potential impact upon industry, science, and health care. Professor John Mattick of the Institute for Molecular Biosciences has commented upon the scope of these patents:

\footnotetext{
I think the chances they'll be challenged somewhere are very, very highsimply because unlike other patents, this one-whatever its validity in terms of inventiveness, claims provenance over $98 \%$ of the human genome, and not just the human genome-the bovine genome, the eucalyptus genome-any genome. So that's another part of the problem with it-that it's very problematical whether it's inventive, but it's just as problematical in terms of its scope and I think that you know there is imbalance between-even if we accept that it's inventive, there's an imbalance between the level of inventiveness and the level of impact that this thing has. ${ }^{263}$
}

The important point is that the non-coding DNA patents have a general application, and have been used in research in the fields of agriculture, health, and the environment. There has been much animated discussion as to whether such far-reaching and extravagant patent claims are sustainable in light of the scientific prior art.

The robust licensing strategies of GTG have caused some consternation amongst private biotechnology companies, health care providers, and public researchers. GTG has sought significant commercial licence fees from an array of biotechnology companies who are engaged in genetic testing of plants, animals, and humans. The firm has hoped that companies would be willing to pay royalties, rather than endure the expensive, risky and time-consuming process of patent litigation. GTG has also sought research licence fees from universities and research institutions. The company has also sought to claim licence fees from public hospitals which are conducting clinical genetic tests. Perhaps the licensing 
tactics of GTG are symptomatic of a wider phenomenon. As Adam Jaffe and Josh Lerner have observed,

\begin{abstract}
Firms have always been eager to make money, and are always willing to exploit the legal system when it presents opportunity for commercial advantage. The granting of patents on important inventions has frequently involved controversy, and the exclusivity has always been a source of concern and unease. ${ }^{264}$
\end{abstract}

In response to its licensing strategy, GTG has faced concerted opposition. Several private biotechnology companies, most notably Applera, have questioned the validity of its patents, in light of the scientific prior art. The ADHB took preemptive action against GTG for groundless threats of legal proceedings. Some private companies have voiced complaints about GTG in the media. The Chief Scientist of Sequenom Inc. complained that its tactics involved "blackmail." Scientists from universities and public researchers have been busy documenting scientific publications and research as prior art that could undermine the validity of GTG's patents. It is uncertain whether the business model of GTG will be viable in the long term. In spite of its robust approach, the company has struggled to generate profits from its licence fees.

Since the settlement of the legal actions with Applera and ADHB, GTG has become embroiled in a new conflict. In August 2005, GTG and the agricultural biotechnology firm, Monsanto, entered into negotiations surrounding the use of the non-coding DNA and genomic mapping patents. ${ }^{265}$ In February 2006, Dr Jacobson of GTG alleged that Monsanto had infringed its non-coding DNA patents through its DNA marker mapping and marker assisted breeding. ${ }^{266}$ In June 2006, Monsanto brought a legal action in the United States District Court for the Eastern District of Missouri. ${ }^{267}$ The company noted that "GTG's aggressive actions have created a reasonable apprehension on the part of Monsanto that it will face an infringement suit under the non-coding DNA patents [...] based upon Monsanto's activities in using DNA markers." 268 Calling for a jury trial, Monsanto has sought a declaration that a patent held by the Australian company GTG was invalid. Alternatively, Monsanto sought a declaration that it was not infringing the patent held by GTG. The litigation between Monsanto and GTG will have wider implications for patent law, research tools, and agricultural biotechnology.

The dispute over the non-coding DNA and genomic-mapping patents reveals fault lines between the disciplines of law and science. In this particular case, there has been a disjunction between the judgments of inventiveness by the patent office and the courts, and the scientific assessments of the relative influence and significance of such research. Mervyn Jacobson of GTG maintains that law and science are polar opposites:

264. Adam Jaffe \& Josh Lerner, Innovation and its Discontents: How Our Broken Patent System is Endangering Innovation and Progress, and What to Do About It (Princeton: Princeton University Press, 2004) at p. 76.

265. Complaint, Monsanto Company v. Genetic Technologies Limited, No. 3:06-cv-00989-HEA (ED Mo 2006) at para. 10

266. Ibid. at para. 10

267. Ibid. at para. 1.

268. Ibid. at para. 11. 
You are talking about two separate laws....You have the laws of science, which are absolute, where you can prod and pursue in the search of truth. Then you have the rules of law, which, especially in the case of patenting, are a hodgepodge of man-made rules to create a workable procedure....

I know of scientists who have "secret inventions" that they don't consider to be patentable-but quite often they are wrong. The final patent may be much more powerful than he or she would ever have understood. ${ }^{269}$

Arguably, though, Jacobson is presenting a false dichotomy between law and science, nature and man. Ideally, law and science should operate in harmony and balance, rather than in opposition and dissonance. ${ }^{270}$ There is a need for patent law to be informed by an understanding and appreciation of science. There is a need to recalibrate the patent system, so as to promote scientific research. The criteria of novelty and inventiveness should be applied rigorously in light of the knowledge of a person skilled in the art, taking into account an inventor's capacity for creativity and complex problem-solving. The requirement of utility should be applied forcefully by patent offices and courts to prevent biotechnology companies from patenting genes without any knowledge of their function. Thus, researchers and scientists should be shielded by a defence of experimental use in respect of research on patented inventions. Furthermore, there should be a defence for personal, non-commercial use of inventions. There could be scope for mechanisms within the patent system to allow access to important research tools in the field of the biological sciences.

There have been concerns expressed about gene patents and their impact on the cost of medical genetic testing, access to genetic counselling and health services, and the development of laboratory testing and expertise. The royalty and licence fees demanded of ADHB by GTG would be a significant proportion of the annual budget of many diagnostic genetics laboratories in Australia, New Zealand, Canada, and the US. In his documentary Patently a Problem, Jonathan Holmes questioned: "Are the public health benefits of speedy diagnoses and groundbreaking research being jeopardised in a rush for a biotech bonanza?"271 There is a need to reform the patent system to ensure the best possible outcomes in respect of clinical research, patient care, and the administration of health care. Medical practitioners, and the clinical providers in respect of genetic tests, should enjoy a limited liability in respect of patent infringement. Health departments should take note of the activism of the ADHB and the Institut Curie, and play a much more proactive role in intervening in patent proceedings. Public sector authorities should challenge patent applications and seek revocation of granted patents, which have an adverse impact upon health care. Furthermore, there should be greater use of compulsory licensing, Crown use, and competition law to secure access to patented inventions on reasonable terms.

269. Binning, "Laws of Uncertainty," supra note 8; for a similar statement, see the statements of Jacobson in an interview with a venture capitalist magazine: Paul D. Ryan, "The Alchemist," The Australian Anthill (3 August 2005), <http://www.australiananthill.com/main.php?page=ed_inside_issue11>.

270. The law and science movement is particularly interested in such matters. See for instance, Gary Edmond, "Judicial Representations of Scientific Evidence," (2000) 63 Modern Law Review 216.

271. Holmes, "Patently a Problem," supra note 19 
Table 1. GTG: Corporate Group

\section{PARENT COMPANY}

Genetic Technologies Limited

\section{SUBSIDIARIES}

\begin{tabular}{|c|}
\hline $75.8 \%$ \\
Gtech \\
International \\
Resources \\
Ltd
\end{tabular}

\begin{tabular}{|c|}
\hline $100 \%$ \\
Simons \\
GeneType \\
Diagnostics \\
Pty Ltd \\
\hline
\end{tabular}

\begin{tabular}{|c|}
\hline $100 \%$ \\
RareCellect \\
Ltd
\end{tabular}

\begin{tabular}{|c|}
$65 \%$ \\
ImmunAid \\
Pty Ltd \\
\end{tabular}

$100 \%$
GeneType
AG
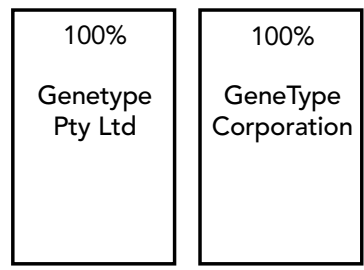

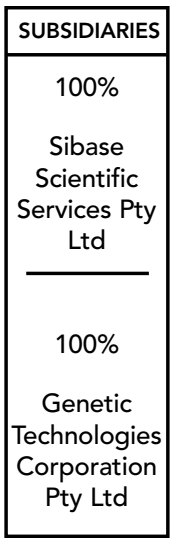

\begin{tabular}{c}
\hline SUBSIDIARY \\
\hline $50.1 \%$ \\
$\begin{array}{c}\text { AgGenomics } \\
\text { Pty Ltd }\end{array}$ \\
\hline
\end{tabular}

Source: GTG Annual Report 2006 at p. 44. 
Table 2. GTG: Key Patents

A. Intron sequence analysis method for detection of adjacent and remote locus alleles as haplotypes

United States Patent

Simons

Inventors:

Assignee:

Appl. No.:

Filed:

Current U.S. Class:

Intern'l Class:

Field of Search:

Patent Family (US and International)
$5,612,179$

18 March 1997

Simons; Malcolm J. (Fryerstown, NZ)

GeneType A.G. (Zug, CH)

949652

23 September 1992

$435 / 6 ; 435 / 91.1 ; 435 / 91.2 ; 536 / 23.1 ; 536 / 24.3 ; 536 / 24.31$; $536 / 24.33$

C12Q 001/68; C12P 019/34; C07H 021/04; C12N 015/00

$435 / 91,6,91.1,91.5,91.2935 / 77,78$

$536 / 24.31,24.32,23.1,23.5,25.3$

$\begin{array}{llll}\text { USA } & 5612179 & \text { Granted } & \text { 25-Aug-89 } \\ \text { USA } & 5192659 & \text { Granted } & \text { 25-Aug-89 } \\ \text { Australia } & 672519 & \text { Granted } & \text { 25-Aug-89 } \\ \text { Australia } & 654111 & \text { Granted } & \text { 25-Aug-89 } \\ \text { Austria } & \text { E144797 } & \text { Granted } & \text { 25-Aug-89 } \\ \text { Belgium } & 414469 & \text { Granted } & \text { 25-Aug-89 } \\ \text { Canada } & 2023888 & \text { Granted } & \text { 25-Aug-89 } \\ \text { Denmark } & 414469 & \text { Granted } & \text { 25-Aug-89 } \\ \text { Europe } & 414469 & \text { Granted } & \text { 25-Aug-89 } \\ \text { France } & 414469 & \text { Granted } & \text { 25-Aug-89 } \\ \text { Germany } & 69029018.7 & \text { Granted } & \text { 25-Aug-89 } \\ \text { Germany } & 299319 & \text { Granted } & \text { 25-Aug-89 } \\ \text { Great Britain } & 414469 & \text { Granted } & \text { 25-Aug-89 } \\ \text { Greece } & 3022410 & \text { Granted } & \text { 25-Aug-89 } \\ \text { Hong Kong } & 1008053 & \text { Granted } & \text { 25-Aug-89 } \\ \text { Israel } & 95467 & \text { Granted } & \text { 25-Aug-89 } \\ \text { Italy } & 414469 & \text { Granted } & \text { 25-Aug-89 } \\ \text { Japan } & 2001-092923 & \text { Pending } & \text { 25-Aug-89 } \\ \text { Japan } & 3206812 & \text { Granted } & \text { 25-Aug-89 } \\ \text { Liechtenstein } & 414469 & \text { Granted } & \text { 25-Aug-89 } \\ \text { Luxembourg } & 414469 & \text { Granted } & \text { 25-Aug-89 } \\ \text { Netherlands } & 414469 & \text { Granted } & \text { 25-Aug-89 } \\ \text { New Zealand } & 235051 & \text { Granted } & \text { 25-Aug-89 } \\ \text { Singapore } & 47747 & \text { Granted } & \text { 25-Aug-89 } \\ \text { South Africa } & 90 / 6765 & \text { Granted } & \text { 25-Aug-89 } \\ \text { Spain } & 2095859 & \text { Granted } & \text { 25-Aug-89 } \\ \text { Sweden } & 90309107.2 & \text { Granted } & \text { 25-Aug-89 } \\ \text { Switzerland } & 414469 & \text { Granted } & \text { 25-Aug-89 } \\ \text { USA } & 1361169 & \text { Pending } & \text { 25-Aug-89 } \\ \text { USA } & 9 / 935998 & \text { Pending } & \text { 25-Aug-89 }\end{array}$




\begin{abstract}
The present invention provides a method for detection of at least one allele of a genetic locus and can be used to provide direct determination of the haplotype. The method comprises amplifying genomic DNA with a primer pair that spans an intron sequence and defines a DNA sequence in genetic linkage with an allele to be detected. The primer-defined DNA sequence contains a sufficient number of intron sequence nucleotides to characterize the allele. Genomic DNA is amplified to produce an amplified DNA sequence characteristic of the allele. The amplified DNA sequence is analysed to detect the presence of a genetic variation in the amplified DNA sequence such as a change in the length of the sequence, gain or loss of a restriction site or substitution of a nucleotide. The variation is characteristic of the allele to be detected and can be used to detect remote alleles. Kits comprising one or more of the reagents used in the method are also described.
\end{abstract}

\title{
Summary of Invention
}

Allelic variants of genetic loci have been correlated to malignant and non-malignant monogenic and multigenic diseases. For example, monogenic diseases for which the defective gene has been identified include DuChenne muscular dystrophy, sickle-cell anemia, Lesch Nyhan syndrome, hemophilia, beta-thalassemia, cystic fibrosis, polycystic kidney disease, ADA deficiency, alpha.-1-antitrypsin deficiency, Wilm's tumor and retinoblastoma. Other diseases which are believed to be monogenic for which the gene has not been identified include fragile $X$ mental retardation and Huntington's chorea.

Genes associated with multigenic diseases such as diabetes, colon cancer and premature coronary athero-sclerosis have also been identified.

In addition to identifying individuals at risk for or carriers of genetic diseases, detection of allelic variants of a genetic locus have been used for organ transplantation forensics, disputed paternity and a variety of other purposes in humans.

In commercially important plants and animals, genes have not only been analyzed but genetically engineered and transmitted into other organisms.

\section{Key Claims of 36 Claims}

1. A method for detection of at least one coding region allele of a multi-allelic genetic locus comprising:

a) amplifying genomic DNA with a primer pair that spans a non-coding region sequence, said primer pair defining a DNA sequence which is in genetic linkage with said genetic locus and contains a sufficient number of non-coding region sequence nucleotides to produce an amplified DNA sequence characteristic of said allele; and

b) analysing the amplified DNA sequence to detect the allele.

9. A method for detection of at least one allele of a multi-allelic genetic locus comprising:

a) amplifying genomic DNA with a primer pair that spans a non-coding region sequence, said primer pair defining a DNA sequence which is in genetic linkage with said allele and contains a sufficient number of non-coding region sequence nucleotides to produce an amplified DNA sequence characteristic of said allele; and

b) analysing said amplified DNA sequence to determine the presence of a genetic variation in said amplified sequence to detect the allele. 


\section{B. Genomic Mapping Method By Direct Haplotyping Using Intron Sequence Analysis}

United States Patent

Simons

Inventors:

Assignee:

Appl. No.:

Filed:

Current U.S. Class:

Intern'l Class:

Field of Search:

Patent Family
(US and International)
$5,851,762$

\section{December 1998}

Simons; Malcolm J. (Glenluce, AU)

Gene Type AG (CH)

293779

22 August 1994

$435 / 6 ; 435 / 91.1 ; 435 / 91.2 ; 435 / 91.53$

C12Q 001/68; C12P 019/34

$435 / 6,91.53,91.1,91.2536 / 24.31$

$\begin{array}{llll}\text { USA } & 5851762 & \text { Granted } & 11-J u l-90 \\ \text { Australia } & 647806 & \text { Granted } & 11-J u l-90 \\ \text { Austria } & 185377 & \text { Granted } & 11-J u l-90 \\ \text { Belgium } & 570371 & \text { Granted } & 11-J u l-90 \\ \text { Canada } & 2087042 & \text { Pending } & 11-J u l-90 \\ \text { Denmark } & 570371 & \text { Granted } & 11-J u l-90 \\ \text { Europe } & 570371 & \text { Granted } & 11-J u l-90 \\ \text { France } & 570371 & \text { Granted } & 11-J u l-90 \\ \text { Germany } & 69131691 & \text { Granted } & 11-J u l-90 \\ \text { Great Britain } & 570371 & \text { Granted } & 11-J u l-90 \\ \text { Ireland } & 570371 & \text { Granted } & 11-J u l-90 \\ \text { Israel } & 98793 & \text { Granted } & 11-J u l-90 \\ \text { Italy } & 570371 & \text { Granted } & 11-J u l-90 \\ \text { Japan } & 3409796 & \text { Granted } & 11-J u l-90 \\ \text { Liechtenstein } & 570371 & \text { Granted } & 11-J u l-90 \\ \text { Luxembourg } & 570371 & \text { Granted } & 11-J u l-90 \\ \text { Netherlands } & 570371 & \text { Granted } & 11-J u l-90 \\ \text { New Zealand } & 238926 & \text { Granted } & 11-J u l-90 \\ \text { South Africa } & 91 / 5422 & \text { Granted } & 11-J u l-90 \\ \text { Sweden } & 91912887.6 & \text { Granted } & 11-J u l-90 \\ \text { Switzerland } & 570371 & \text { Granted } & 11-J u l-90 \\ \text { USA } & 5789568 & \text { Granted } & 25-\text { Aug-89 } \\ \text { Europe } & \text { EP0660877 } & \text { Granted } & 01-\text { Nov-91 } \\ \text { France } & \text { FR660877 } & \text { Granted } & 01-\text { Nov-91 } \\ \text { Germany } & \text { DE69232726.6 } & \text { Granted } & 01-\text { Nov-91 } \\ \text { Great Britain } & \text { GB0660877 } & \text { Granted } & 01-N o v-91 \\ \text { USA } & \text { US6383747 } & \text { Granted } & 01-N o v-91 \\ \text { Australia } & 2005900728 & \text { Pending } & 16-\text { Feb-05 } \\ \text { Australia } & 2005904603 & \text { Pending } & 24-\text { Aug-05 }\end{array}$

\footnotetext{
Abstract

The present invention is an improved genomic mapping method which is able to generate highly informative polymorphic sites throughout the genome. In addition to being highly polymorphic, the sites can be used to generate patterns that identify allelic and sub-allelic haplotypes associated with the region.
} 


\section{Summary of Invention}

The present mapping method utilizes direct determination of haplotypes through analysis of an individual's genomic DNA. The present mapping method provides a way to obtain information regarding the amount of polymorphism associated with any genetic region of interest and to identify individuals having different alleles and haplotypes for the genetic region. In addition, the method provides information as to the distance and direction of a gene of interest, particularly a disease gene, from a given genetic locus. This method is particularly useful for locating disease genes that are not associated with chromosomal rearrangements.

The method also provides a rapid way to generate polymorphic markers throughout the genome, particularly in any genetic locus of interest. Not only can the markers be identified and screened more readily than classical RFLP sites, but the markers are much more informative than classical RFLP sites, which are either present or absent at any given location.

The present invention is based on the finding that non-coding region sequences, particularly intron sequences, contain genetic variations that are characteristic of alleles of adjacent and remote, linked genetic loci on the chromosome. In particular, primer-defined, amplified DNA sequences that include a sufficient number of intron sequence nucleotides can be used to produce patterns which are characteristic of alleles and haplotypes associated with a genetic region of interest. The patterns can be produced by gel electrophoresis length differences in the amplified DNA sequences or can be RFLP fragment patterns produced by digestion of the amplified DNA sequences with one or more endonucleases. Alternatively, once sufficient sequence information has been obtained, allele/haplotype-specific amplification can be used to detect the presence of the selected allele/haplotype.

The mapping method provides information about the degree of polymorphism of a genetic locus by determining the number of allelic and sub-allelic (haplotypic) patterns produced for the locus by analysing the DNA of numerous individuals. The method can be used to screen individuals to explore individual variation associated with a genetic locus of interest. The method also provides information regarding disease-associated genetic loci that can be used to study the population genetics of a disease, particularly monogenic disease.

\section{Key Claims of 36 Claims}

1. A genomic mapping method for identifying informative, polymorphic markers and using said markers to identify a chromosomal region associated with a trait, comprising:

a) obtaining a first set of genomic DNA samples from a plurality of individuals representing the diversity of a general population;

b) amplifying a non-coding sequence from a selected chromosomal region in each of said first set of genomic DNA samples to produce a first set of amplified DNA sequences;

c) analysing said first set of amplified DNA sequences to determine whether said noncoding sequence comprises a plurality of polymorphic regions, wherein said plurality of polymorphic regions defines a plurality of haplotypic patterns detectable by a selected technique for analysing genetic variation;

d) determining the number of haplotypic patterns associated with said non-coding sequence that are distinct as measured by said selected technique, wherein each haplotypic pattern is a marker for a haplotype of said selected chromosomal region;

9. A genomic mapping method for identifying a chromosomal region associated with a trait, comprising:

a) obtaining genomic DNA samples from a plurality of individuals with the trait from a general population, wherein said plurality of individuals with the trait is not derived from a single family; 
b) amplifying a plurality of non-coding sequences from a series of selected chromosomal regions in each genomic DNA sample to produce a plurality of amplified DNA sequences, wherein each selected chromosomal region comprises a plurality of polymorphic non-coding regions, and said plurality of polymorphic non-coding regions defines a plurality of haplotypic patterns detectable by a selected technique for analysing genetic variation;

c) analysing said plurality of amplified DNA sequences to identify the haplotype of each corresponding selected chromosomal region;

d) determining the degree of restriction in haplotype heterogeneity at each selected chromosomal region for said plurality of individuals with the trait, as compared to said general population; and

e) comparing the degree of haplotype heterogeneity restriction across said selected chromosomal regions to identify a subseries of adjacent selected chromosomal regions having a greater degree of haplotype heterogeneity restriction at a central selected chromosomal region in said subseries than at selected chromosomal regions at the ends of said subseries as an indication that said central selected chromosomal region is associated with the trait.

\section{Foetal Cell Recovery Method}

United States Patent

Simons

Inventors:

Assignee:

Appl. No.:

Filed:

PCT Filed:

PCT NO:

371 Date:

102(e) Date:

PCT PUB. NO.:

PCT PUB. Date:

Current U.S. Class:

Intern'l Class:

Field of Search:
$5,447,842$

5 September 1995

Simons; Malcolm J. (Glenluce, AU)

GeneType A.G. (Zug, CH)

927313

2 November 1992

27 March 1991

PCT/AU91/00115

2 November 1992

2 November 1992

W091/14768

3 October 1991 $435 / 378$

C12Q 001/24; C12Q 001/68

$435 / 2,6,7.21,7.24,7.25,29,30,240.2$ 


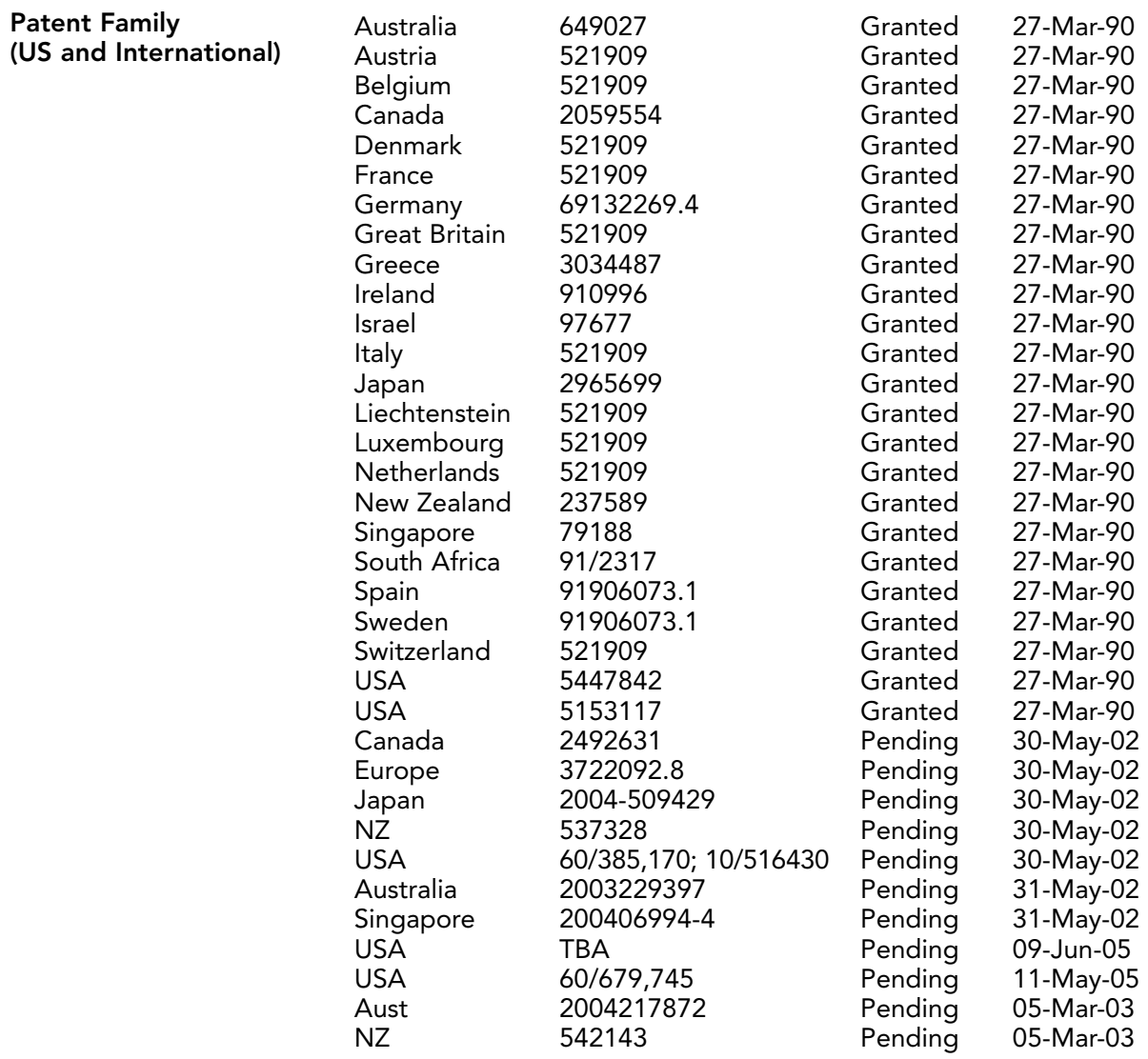

\begin{abstract}
The present invention provides a method for selectively recovering foetal cells from a maternal blood sample. The method is performed on a blood sample from a pregnant woman having different first and second cell surface antigens expressed by a first allele of a polymorphic genetic locus and a second allele of a polymorphic genetic locus. The method separates maternal and foetal cells based on differential reactivities of the cells to antibodies specific for polymorphic cell surface antigens, particularly the HLA antigens. In particular, the foetal and maternal cells are separated based on the non-reactivity of the foetal cells to an antibody specific for a cell surface antigen encoded by a non-transmitted maternal allele. The method can be performed using solid phase-affixed antibody and recovering non-bound cells or using fluorescent labelled antibody and recovering unlabeled cells by fluorescence-activated cell sorting. In a preferred embodiment, the cells are also contacted with a second antibody specific for the second cell surface antigen. Foetal cells are separated based on their reaction with, at most, one of the antibodies.
\end{abstract}




\title{
D. Other Patent Applications
}

\section{ACTN3 Sports Performance Testing}

ACTN3 patent applications filed (16 September 2002) in Australia, Canada, China, Europe, India, Japan, New Zealand, Russia, South Korea, and USA. Markers of predisposition to addictive states also filed in Australia and the United States (8 November 2004 and 24 August 2005). Use of VNTRs patent filed in the USA (1 October 2003).

\begin{abstract}
For the first time anywhere in the world, we are able to offer a genetic test to determine whether you are naturally geared toward sprint/power events or towards endurance sporting ability. The test examines a gene known as ACTN3, which produces a structural protein found in fast-twitch muscle fibres. Research involving elite-level athletes from the Australian Institute of Sport has shown that the different forms ("variations") of the ACTN3 gene may be associated with an improved ability to excel in either sprint/power events, or in endurance events. So whether you're an athlete, or young athlete-to-be, the ACTN3 Sports Performance Test will help direct you toward achieving your maximum natural potential.
\end{abstract}

Available at Internet Archive, <http://web.archive.org/web/20060819074939/http://www. genetictechnologies.com.au/index_athletic.asp?menuid=110>

\section{ImmunAid}

Retroviral immunotherapy patent applications filed (18 August 2000) in Australia, Brazil, Canada China, Europe, Japan, Singapore, and the USA; and granted in New Zealand and South Africa. Strategy for retroviral immunotherapy filed (20 February 2002) in Australia, Brazil, Canada, China, Europe, Japan, New Zealand, Singapore and South Africa. Cancer therapy patent applications filed (14 February 2002) in Australia, Brazil, Canada, China, Europe, Japan, New Zealand, Singapore, South Africa, and the USA.

\begin{abstract}
A technical review committee, which includes specialists in the field of HIV / AIDS and cancer, has been established to oversee the scientific activity of the ImmunAid program. This committee recently recommended that ImmunAid begin human monitoring trials. ImmunAid Pty Ltd then obtained ethical approval to commence these trials, which are underway in Sydney, Melbourne and Perth. The mouse data have now been accepted for publication in the journal The Journal of Immunology, in a paper entitled "Timed ablation of regulatory CD4+ T-cells can prevent murine AIDS progression." It is now planned to expand the human monitoring trials for patients with AIDS and patients with ovarian and possibly other cancers. It should soon become clear if a pathway exists to carry this work forward to a therapy for humans infected with HIV.
\end{abstract}

Available at Internet Archive, <http://web.archive.org/web/20060105113257/http://www.gtg. com.au/index_general.asp?menuid=170.030.020>

\section{Animal Parasites}

Patent applications in respect of a genetic test for cryptosporidium filed in Australia, Brazil, Canada, China, Europe, Japan, New Zealand, Mexico and the USA (21 August 2002).

\section{Laboratory Techniques}

Patents granted in respect of laboratory techniques in France, Germany, Great Britain, Sweden, and the USA (11 July 1990). 
Table 3. GTG: Commercial and Research Licences

\begin{tabular}{|c|c|c|c|c|c|c|}
\hline No. & Name & Location & Field & Date & Licence & Value \\
\hline 1 & $\begin{array}{l}\text { Genetic Solutions } \\
\text { Pty Ltd }\end{array}$ & $\begin{array}{l}\text { Queensland, } \\
\text { AUS }\end{array}$ & $\begin{array}{l}\text { Livestock } \\
\text { Genomics }\end{array}$ & $\begin{array}{l}30 \text { November } \\
2001\end{array}$ & Commercial & Confidential \\
\hline 2 & $\begin{array}{l}\text { Sequenom, } \\
\text { Inc }\end{array}$ & $\begin{array}{l}\text { San Diego, } \\
\text { USA }\end{array}$ & $\begin{array}{l}\text { Medical } \\
\text { Genomics }\end{array}$ & $\begin{array}{l}5 \text { April } \\
2002\end{array}$ & Commercial & $\begin{array}{l}\text { AU\$ } \\
1 \text { million }\end{array}$ \\
\hline 3 & $\begin{array}{l}\text { Nanogen, Inc. - } \\
\text { Effective Date } \\
12 \text { April } 2002\end{array}$ & $\begin{array}{l}\text { San Diego, } \\
\text { USA }\end{array}$ & $\begin{array}{l}\text { Genetic } \\
\text { Diagnostics }\end{array}$ & $\begin{array}{l}12 \text { April } \\
2002\end{array}$ & Commercial & $\begin{array}{l}\text { AU\$ } \\
620,000\end{array}$ \\
\hline 4 & Inguran LP & Texas, USA & Livestock & $\begin{array}{l}12 \text { June } \\
2002\end{array}$ & Commercial & $\$ 230,000$ \\
\hline 5 & $\begin{array}{l}\text { Perlegen Sciences } \\
\text { Inc }\end{array}$ & $\begin{array}{l}\text { Mountain View, } \\
\text { California, USA }\end{array}$ & $\begin{array}{l}\text { Genome } \\
\text { Analysis }\end{array}$ & $\begin{array}{l}20 \text { August } \\
2002\end{array}$ & Commercial & $\begin{array}{l}\text { AU\$ } \\
1.6 \text { million }\end{array}$ \\
\hline 6 & $\begin{array}{l}\text { Myriad Genetics, } \\
\text { Inc. }\end{array}$ & $\begin{array}{l}\text { Salt Lake City, } \\
\text { Utah, USA }\end{array}$ & $\begin{array}{l}\text { Genetic } \\
\text { Diagnostics }\end{array}$ & $\begin{array}{l}28 \text { October } \\
2002\end{array}$ & Commercial & $\begin{array}{l}\text { AU\$ } \\
1.85 \text { million }\end{array}$ \\
\hline 7 & $\begin{array}{l}\text { Biotage (formerly } \\
\text { Pyrosequencing } A B \text { ) }\end{array}$ & SWE & Reagants & $\begin{array}{l}7 \text { March } \\
2003\end{array}$ & Commercial & $\begin{array}{l}\text { AU\$ } \\
5 \text { million }\end{array}$ \\
\hline 8 & $\begin{array}{l}\text { Orchid Biosciences } \\
\text { Inc }\end{array}$ & $\begin{array}{l}\text { New Jersey, } \\
\text { USA }\end{array}$ & $\begin{array}{l}\text { Paternity and } \\
\text { Forensic Testing }\end{array}$ & $\begin{array}{l}27 \text { May } \\
2003\end{array}$ & Commercial & Confidential \\
\hline 9 & $\begin{array}{l}\text { Association of } \\
\text { Regional and } \\
\text { University Pathologists }\end{array}$ & $\begin{array}{l}\text { Salt Lake City, } \\
\text { Utah, USA }\end{array}$ & Pathology & $\begin{array}{l}31 \text { March } \\
2003\end{array}$ & Commercial & $\begin{array}{l}\text { AU\$ } \\
125,000\end{array}$ \\
\hline 10 & $\begin{array}{l}\text { Quest Diagnostics } \\
\text { Ltd }\end{array}$ & $\begin{array}{l}\text { New Jersey, } \\
\text { USA }\end{array}$ & $\begin{array}{l}\text { Genetic } \\
\text { Diagnostics }\end{array}$ & $\begin{array}{l}1 \text { August } \\
2003\end{array}$ & Commercial & Confidential \\
\hline 11 & $\begin{array}{l}\text { TM Biosciences } \\
\text { Corporation Canada }\end{array}$ & $\begin{array}{l}\text { Toronto, } \\
\text { CAN }\end{array}$ & $\begin{array}{l}\text { Genetic } \\
\text { Diagnostics }\end{array}$ & $\begin{array}{l}31 \text { December } \\
2003\end{array}$ & Commercial & Confidential \\
\hline 12 & $\begin{array}{l}\text { C.Y. O'Connor ERADE } \\
\text { Village Foundation, } \\
\text { Australia }\end{array}$ & AUS & $\begin{array}{l}\text { Genetic } \\
\text { Diagnostics }\end{array}$ & $\begin{array}{l}\text { June } \\
2004\end{array}$ & Commercial & Confidential \\
\hline 13 & Ovita & $\begin{array}{l}\text { Dunedin, } \\
\text { NZL }\end{array}$ & $\begin{array}{l}\text { Sheep } \\
\text { Genomics }\end{array}$ & $\begin{array}{l}28 \text { June } \\
2004\end{array}$ & Commercial & Confidential \\
\hline 14 & $\begin{array}{l}\text { Genzyme } \\
\text { Corporation }\end{array}$ & USA & $\begin{array}{l}\text { Human } \\
\text { Genetic Testing }\end{array}$ & $\begin{array}{l}17 \text { September } \\
2004\end{array}$ & Commercial & $\begin{array}{l}\text { AU\$ } \\
7.5 \text { million }\end{array}$ \\
\hline 15 & Metamorphix & USA & Animal Genetics & $\begin{array}{l}4 \text { October } \\
2004\end{array}$ & Commercial & $\begin{array}{l}\text { AU\$ } \\
1.8 \text { million }\end{array}$ \\
\hline 16 & $\begin{array}{l}\text { Vialactia Biosciences } \\
\text { (NZ) Ltd }\end{array}$ & NZL & Dairy Industry & $\begin{array}{l}8 \text { October } \\
2004\end{array}$ & Commercial & Confidential \\
\hline 17 & $\begin{array}{l}\text { Laboratory } \\
\text { Corporation of } \\
\text { America Holdings }\end{array}$ & $\begin{array}{l}\text { North Carolina, } \\
\text { USA }\end{array}$ & $\begin{array}{l}\text { Genetic } \\
\text { Diagnostics }\end{array}$ & $\begin{array}{l}5 \text { November } \\
2004\end{array}$ & Commercial & Confidential \\
\hline
\end{tabular}




\begin{tabular}{|c|c|c|c|c|c|c|}
\hline No. & Name & Location & Field & Date & Licence & Value \\
\hline 18 & $\begin{array}{l}\text { Bionomics } \\
\text { Ltd }\end{array}$ & AUS & $\begin{array}{l}\text { Genetic Testing } \\
\text { for Epilepsy }\end{array}$ & $\begin{array}{l}8 \text { November } \\
2004\end{array}$ & $\begin{array}{l}\text { Commercial } \\
\text { Joint Venture }\end{array}$ & Confidential \\
\hline 19 & $\begin{array}{l}\text { Australian Genome } \\
\text { Research Facility Ltd }\end{array}$ & AUS & Genome Research & $\begin{array}{l}21 \text { January } \\
2005\end{array}$ & Commercial & Confidential \\
\hline $\begin{array}{l}20 / \\
21 / \\
22 / \\
23\end{array}$ & $\begin{array}{l}\text { AgResearch, } \\
\text { HortResearch, } \\
\text { Forest-Research - } \\
\text { and Livestock } \\
\text { Improvement } \\
\text { Corporation }\end{array}$ & NZL & $\begin{array}{l}\text { Agricultural } \\
\text { Genetic Research }\end{array}$ & $\begin{array}{l}30 \text { June } \\
2005\end{array}$ & Commercial & $\begin{array}{l}N Z \$ \\
450,000\end{array}$ \\
\hline 24 & Applera Corporation & USA & Genomics & $\begin{array}{l}30 \text { December } \\
2005\end{array}$ & Commrcial & $\begin{array}{l}\text { AU } \$ \\
15,000,000\end{array}$ \\
\hline 25 & Optigen & USA & $\begin{array}{l}\text { Genetic } \\
\text { Diagnostics for } \\
\text { Purebreed Dogs }\end{array}$ & 23 May 2006 & Commercial & Confidential \\
\hline 26 & Bovigen LLC & USA & $\begin{array}{l}\text { Genetic } \\
\text { Diagnostics for } \\
\text { Livestock }\end{array}$ & 1 June 2006 & Commercial & Confidential \\
\hline 27 & Innogenetics NV & BEL & $\begin{array}{l}\text { Genetic Testing } \\
\text { Kits }\end{array}$ & 30 June 2006 & Commercial & Confidential \\
\hline
\end{tabular}

\begin{tabular}{|c|c|c|c|c|c|c|}
\hline No. & Name & Location & Field & Date & Licence & Value \\
\hline \multirow[t]{2}{*}{1} & University of Utah & USA & Non-Coding & 30 April & Research & Confidential \\
\hline & & & DNA Research & 2003 & & \\
\hline 2 & University of Sydney & AUS & Genetic Research & 22 July 2003 & Research & Confidential \\
\hline \multirow[t]{2}{*}{3} & University of & AUS & Genetic Research & 23 December & Research & Confidential \\
\hline & Technology Sydney & & & 2003 & & \\
\hline \multirow[t]{2}{*}{4} & King's College & GBR & Non-Coding & December & Research & Confidential \\
\hline & & & DNA Research & 2003 & & \\
\hline \multirow[t]{2}{*}{5} & University of & USA & Genetic Research & 20 May & Research & Confidential \\
\hline & Colorado & & & 2004 & & \\
\hline
\end{tabular}

Table up to date as of November 2006. 
Table 4. GTG: Patent Litigation

\begin{tabular}{|c|c|c|c|c|c|}
\hline No. & Parties & Jurisdiction & Complaint Filed & Resolution & Outcome \\
\hline 1 & $\begin{array}{l}\text { Myriad Genetics Inc. } \\
\text { v. Genetic } \\
\text { Technologies Ltd. }\end{array}$ & $\begin{array}{l}\text { US District Court } \\
\text { (D Utah) }\end{array}$ & 26 August 2002 & 22 November 2002 & $\begin{array}{l}\text { Cross-Licensing } \\
\text { Agreement }\end{array}$ \\
\hline 2 & $\begin{array}{l}\text { Genetic Technologies } \\
\text { Ltd. v. Nuvelo Inc. }\end{array}$ & $\begin{array}{l}\text { US District Court } \\
\text { (ND Cal) }\end{array}$ & 26 March 2003 & 12 April 2003 & Settlement \\
\hline 3 & $\begin{array}{l}\text { Genetic Technologies } \\
\text { Ltd. v. Covance Inc. }\end{array}$ & $\begin{array}{l}\text { US District Court } \\
\text { (ND Cal) }\end{array}$ & 26 March 2003 & 12 April 2003 & Settlement \\
\hline 4 & $\begin{array}{l}\text { LabCorp v. Genetic } \\
\text { Technologies Ltd. }\end{array}$ & $\begin{array}{l}\text { US District Court } \\
\text { (D NJ) }\end{array}$ & 22 December 2003 & 20 February 2004 & $\begin{array}{l}\text { Commercial } \\
\text { Licence }\end{array}$ \\
\hline 5 & $\begin{array}{l}\text { Genetic Technologies } \\
\text { Ltd. v. Applera }\end{array}$ & $\begin{array}{l}\text { US District Court } \\
\text { (ND Cal) }\end{array}$ & 26 March 2003 & 30 December 2005 & Settlement \\
\hline 6 & $\begin{array}{l}\text { Auckland District } \\
\text { Health Board v. } \\
\text { Genetic Technologies } \\
\text { Ltd. }\end{array}$ & NZL High Court & 19 August 2004 & 7 July 2005 & Settlement \\
\hline 7 & $\begin{array}{l}\text { Monsanto v. Genetic } \\
\text { Technologies Ltd. }\end{array}$ & $\begin{array}{l}\text { US District Court } \\
\text { (ED Mo) }\end{array}$ & 28 June 2006 & & Ongoing \\
\hline
\end{tabular}

Table up to date as of November 2006. 
